\title{
Geomorphic characterization of the U.S. Atlantic continental margin
}

\author{
Daniel S. Brothers *, Uri S. ten Brink, Brian D. Andrews, Jason D. Chaytor
}

US Geological Survey, Coastal and Marine Science Center, 384 Woods Hole Rd, Woods Hole, MA 02543, United States

\section{A R T I C L E I N F O}

\section{Article history:}

Received 5 June 2012

Received in revised form 14 December 2012

Accepted 20 December 2012

Available online 10 January 2013

Communicated by D.J.W. Piper

\section{Keywords:}

passive margin

continental slope

classification

submarine canyon

seismic reflection

multibeam bathymetry

\begin{abstract}
A B S T R A C T
The increasing volume of multibeam bathymetry data collected along continental margins is providing new opportunities to study the feedbacks between sedimentary and oceanographic processes and seafloor morphology. Attempts to develop simple guidelines that describe the relationships between form and process often overlook the importance of inherited physiography in slope depositional systems. Here, we use multibeam bathymetry data and seismic reflection profiles spanning the U.S. Atlantic outer continental shelf, slope and rise from Cape Hatteras to New England to quantify the broad-scale, across-margin morphological variation. Morphometric analyses suggest the margin can be divided into four basic categories that roughly align with Quaternary sedimentary provinces. Within each category, Quaternary sedimentary processes exerted heavy modification of submarine canyons, landslide complexes and the broad-scale morphology of the continental rise, but they appear to have preserved much of the pre-Quaternary, across-margin shape of the continental slope. Without detailed constraints on the substrate structure, first-order morphological categorization the U.S. Atlantic margin does not provide a reliable framework for predicting relationships between form and process.
\end{abstract}

Published by Elsevier B.V.

\section{Introduction}

The morphology of passive continental margins is shaped by long and complex interactions between constructional and destructional geomorphic processes. Geomorphic characterization of the continental shelf, slope and rise is a first-step toward identifying along-strike variations in constructional and destructional processes that shape continental margins. Past studies have proposed that systematic relationships exist between the major governing processes, such as modern sediment supply, and the shape of the resulting continental margin (Pratson and Haxby, 1996; O'Grady et al., 2000; Goff, 2001). Other studies have described relationships between margin morphology and various sedimentary parameters, including sedimentary texture (Schlager and Camber, 1986; Kenter, 1990), sediment supply (Kenyon and Turcotte, 1985; Orton and Reading, 1993) and sediment transport mechanisms (Galloway, 1998; Adams and Schlager, 2000; Schlager and Adams, 2001; Cacchione et al., 2002). However, in order to assess the relative contributions of these processes to shaping the modern-day margin morphology, one must also establish the relative importance of pre-existing physiography and antecedent geology.

Most previous studies of the U.S. Atlantic Margin (USAM) can be split into two general themes: those focused on discrete morphological features, such as submarine canyons and mass movements (Twichell and Roberts, 1982; O'Leary and Dobson, 1992; Booth et al., 1993; Pratson et al., 1994; McAdoo et al., 2000; Goff, 2001; Mitchell, 2004, 2005, 2006; Chaytor et al., 2009; Gerber et al., 2009; Twichell et al.,

\footnotetext{
* Corresponding author. Tel.: +1 5084572293.

E-mail address: dbrothers@usgs.gov (D.S. Brothers).
}

2009); and those aimed at defining the framework geology of the margin and at understanding its longer-term evolution (Poag, 1978, 1985; Schlee et al., 1979; Austin et al., 1980; Manspeizer, 1985; Mountain and Tucholke, 1985; Hutchinson et al., 1986; Klitgord et al., 1988; Lizarralde and Holbrook, 1997). In this paper we describe and analyze, for the first time, a compilation of multibeam bathymetry data spanning the outer shelf, slope and rise from Cape Hatteras to New England (Fig. 1). The overarching goal is to identify the principal causes of the geomorphic variability along the USAM by (1) quantifying the first-order morphological patterns of the USAM and (2) examining the relationships between margin morphology and the underlying stratigraphic architecture. We also discuss the overall effectiveness of applying geomorphic categorizations to continental slope morphology.

\section{Background}

\subsection{Slope depositional systems}

Continental slopes of passive margins experience fluctuations between constructional phases, where sediment supply and deposition along the shelf edge and slope cause net progradation, and destructional phases that include slope failure, erosion and net retrogression (Van Wagoner et al., 1988; Ross et al., 1994; Galloway, 1998). Slope depositional systems respond to variations in physiography and environmental conditions by adjusting their loci of erosion and deposition. For example, the curvature of the shelf-edge rollover is largely controlled by the environmental energy conditions (Mitchum et al., 1977; Adams and Schlager, 2000; Schlager and Adams, 2001): regions with weak currents tend to be associated with abrupt, or oblique, rollover profiles 


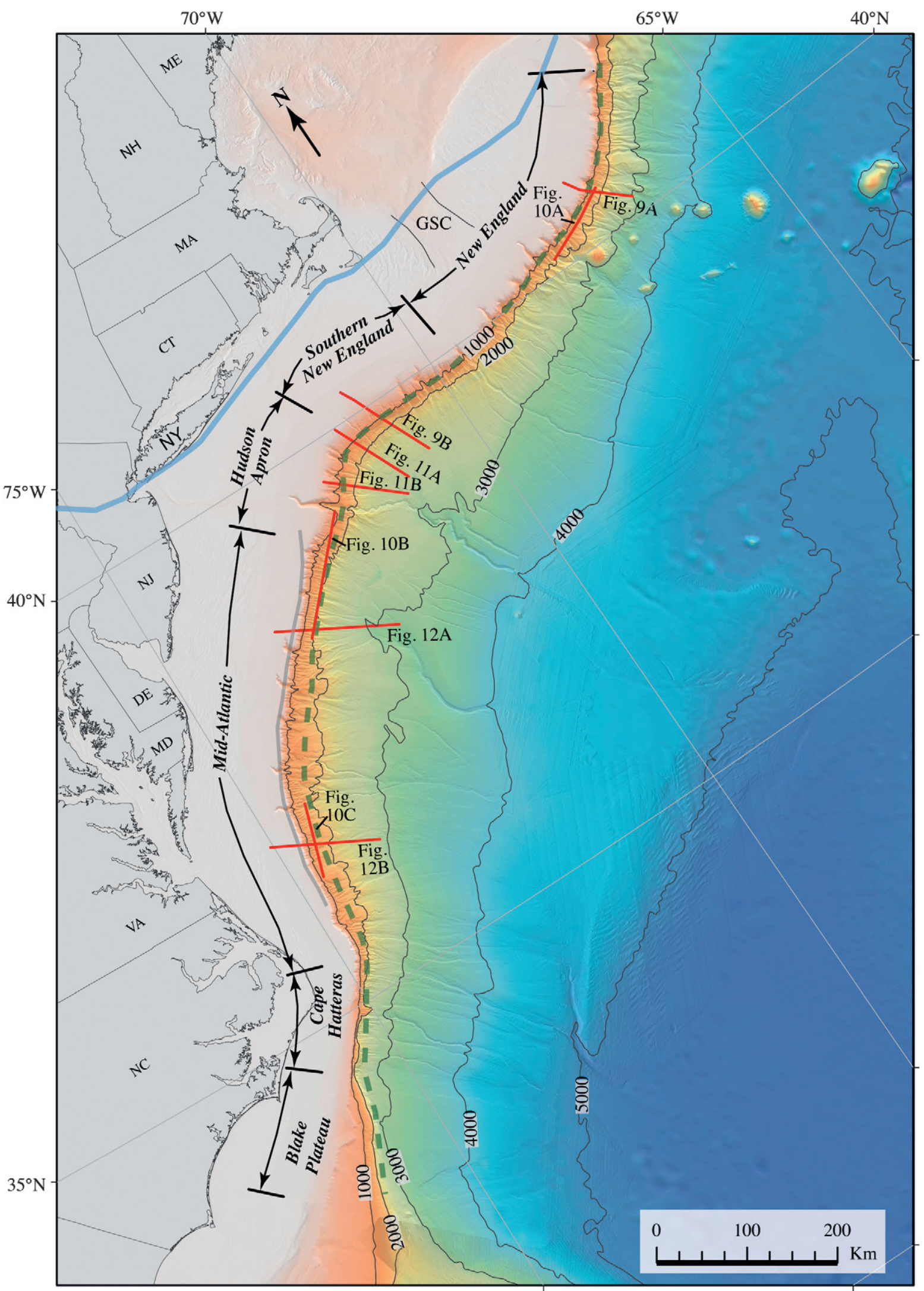

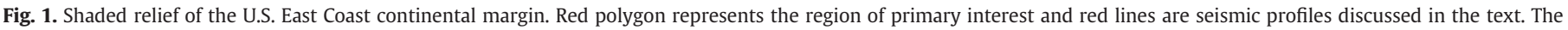

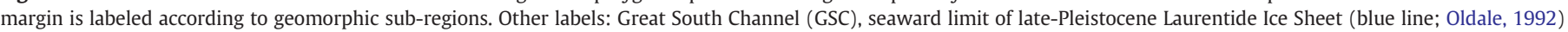

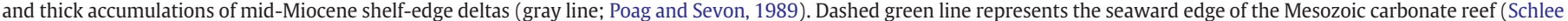
et al., 1979). 
(Fig. 2A), whereas regions with strong wave and current energy characteristically produce rounded, or sigmoidal, profiles (Fig. 2B).

If deposition at the shelf-edge builds the local slope above a critical gradient, the sediment fails, and a component of the failed sediment can be transported down slope as sediment gravity flows (or mass flows). Where mass flows come to rest is, in part, a function of slope and rise physiography, and each depositional/erosional event modifies the slope gradient encountered by subsequent events (Fig. 2C-F). Hence, sedimentary processes acting on the continental shelf-break and upper continental slope operate in concert with mass flow processes of the lower slope and upper rise (Kenyon and Turcotte, 1985; Ross et al., 1994; Galloway, 1998; Gerber et al., 2009). In general, oversteepening of continental slopes may lead to mass wasting and bypass to the lower slope/upper rise (Fig. 2C,D), where the accumulation of mass transport deposits leads to the formation of fan-apron complexes. Eventually, base-of-slope aggradation reduces the total basin relief by creating a lower-gradient platform over which sedimentary clinoforms can prograde across of the upper and middle slope can prograde (Ross et al., 1994; Galloway, 1998).

\subsection{Continental shelf, slope and rise of the U.S. Atlantic margin}

The evolution of the U.S. Atlantic margin has been described in numerous articles (Poag, 1978, 1984, 1985; Schlee et al., 1979; Williams and Hatcher, 1982; Manspeizer, 1985; Dillon and Popenoe, 1988; Klitgord et al., 1988, 1994; Poag and Sevon, 1989; Holbrook et al., 1992; Hutchinson et al., 1996; Olsen, 1997; Withjack and Schlische, 2005; Wyer and Watts, 2006). The major structural boundaries of the margin formed during late Triassic/early Jurassic continental rifting ( 230-185 Ma) (Klitgord et al., 1988; Olsen, 1997). Post-rift subsidence of the passive margin was accompanied by growth of a seaward thickening sedimentary prism containing evaporitic, clastic and carbonate deposits (Mountain and Tucholke, 1985; Poag, 1985; Poag and Sevon, 1989). Total sedimentary thickness varies from the New England margin ( $<6 \mathrm{~km}$ along) southward to the Mid-Atlantic margin $(>12 \mathrm{~km})$ due to differences in lithospheric structure, sediment supply and long-term subsidence rates (Poag, 1985; Klitgord et al., 1988; Poag and Sevon, 1989; Wyer and Watts, 2006).

The post-rift evolution of the continental slope has been characterized by three primary phases of development: carbonate, constructional and destructional (Schlee et al., 1979). Mesozoic (187 to $130 \mathrm{Ma}$ ) limestone reefs and carbonate platforms formed a discontinuous series of shelf-edge sediment dams that extended from the Gulf of Mexico to the eastern Canadian margin (Schlee et al., 1979; Poag, 1985). The dams formed steep seaward facing escarpments, trapping marine calcareous sediment on the landward side. Differences in the modern-day depths of the carbonate platforms are due to along-margin variations in long-term subsidence. The depth from sea level to the top of the

Shelf-edge Adjustment Model
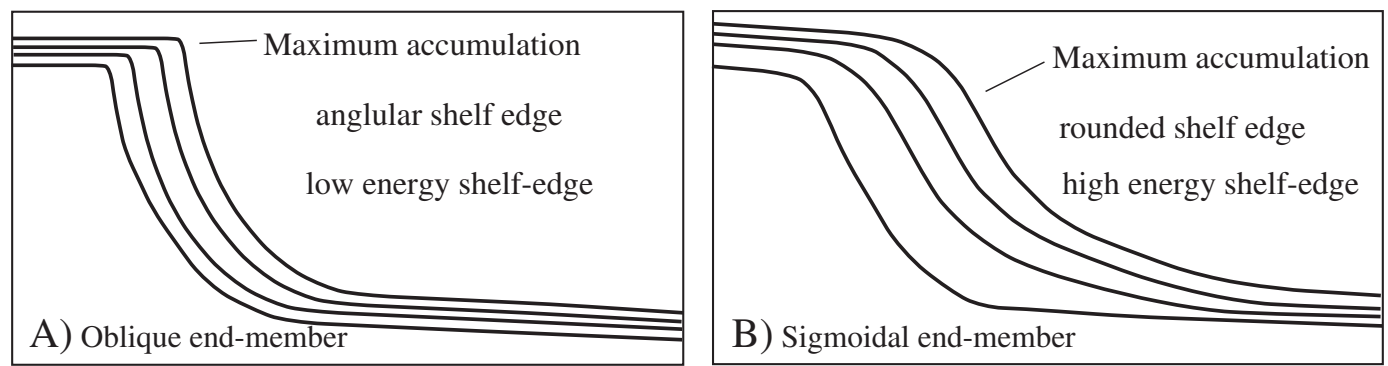

Slope Adjustment Model
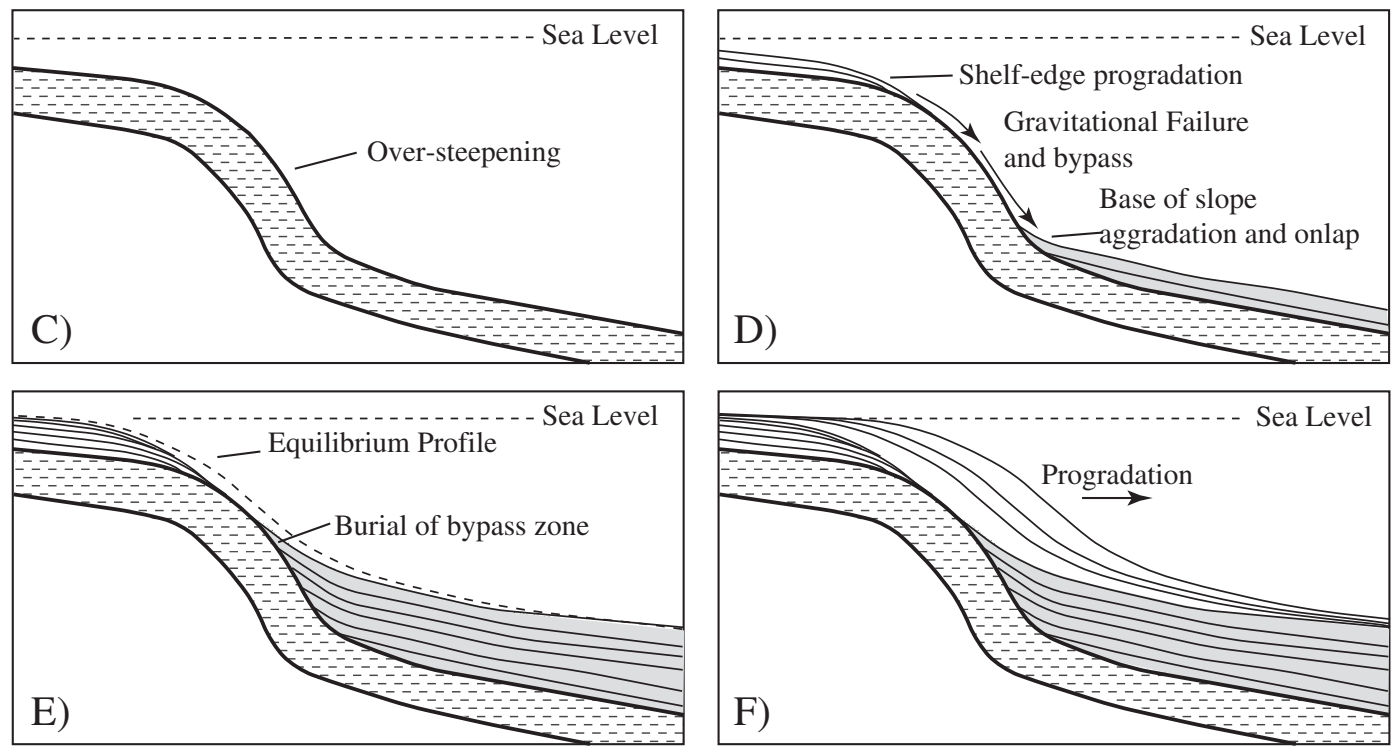

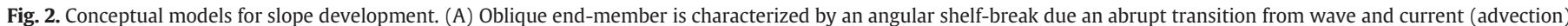

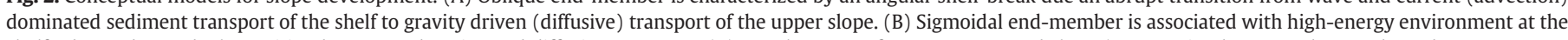

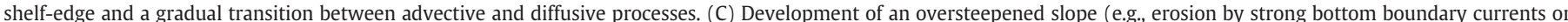

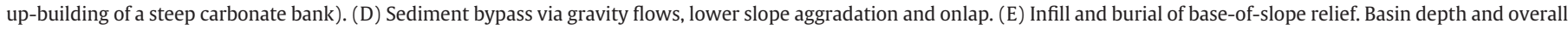
gradient are reduced allowing sediment to prograde along an equilibrium profile (F).

After Ross et al., 1994; Galloway, 1998. 
carbonate platform is 1-1.5 km along the New England slope, 3-4 km off Southern New England, and 5-6 km off the Mid-Atlantic and Cape Hatteras. Along the New England slope, the seaward face of the platform had at least $1500 \mathrm{~m}$ of vertical relief by the Late Cretaceous (Schlee et al., 1979; Austin et al., 1980). Sediment ponded behind the reef banks eventually spilled over during the Early and Late Cretaceous. Margin subsidence and aggradation of continental rise sequences graded the relief across the seaward edge of the reef bank and, in places, allowed slope progradation (Schlee et al., 1979).

The Cenozoic was marked by alternating episodes of slope progradation and truncation, but it is considered a destructional phase because the shelf-edge moved landward relative to the Mesozoic reef (Schlee et al., 1979). Episodes of enhanced deep-water boundary current flow during the Eocene, Oligocene, Miocene and Pliocene formed regional unconformity surfaces that greatly modified the slope/rise morphology (Miller et al., 1985; Mountain and Tucholke, 1985). The Middle Miocene experienced a massive surge in terrestrially derived sediment along the Mid-Atlantic. Deltaic clinoforms of the middle to outer shelf (Fig. 1) accumulated at rates more than twice that of any other period of the Mesozoic-Cenozoic section (Poag, 1984, 1985; Greenlee et al., 1992; Poulsen et al., 1998; Monteverde et al., 2008).

Accommodation on the continental shelf was virtually filled by the end of the Pliocene and sediment began to bypass the shelf, particularly during sea level low stands (Schlee et al., 1979; Poag, 1984). Continental glaciations coupled with extreme variation in eustatic sea level created a period of anomalously high sediment supply to the outer continental shelf and slope during the Pleistocene. A narrow, seaward-thickening, sedimentary wedge (500-600 m thick) that is heavily dissected by submarine canyons underlies much of the Mid-Atlantic and New England shelf-edge (Emery and Uchupi, 1965; Valentine et al., 1980; Poag, 1982; Twichell and Roberts, 1982; Pratson and Coakley, 1996; Mitchell, 2005). Widespread canyon/channel incision of the slope and upper-rise, along with onlapping base-of-slope fan/apron complexes suggest slope failures and generation of mass flows were the dominant sediment transport processes during the Quaternary. Most of the modern-day, short-wavelength $(<5 \mathrm{~km})$ seafloor relief is from mass wasting events and submarine canyon incision that occurred during the Quaternary (Schlee et al., 1979; Twichell et al., 2009). Quaternary deposits covering the lower continental slope of New Jersey and southern New England are thin or absent, suggesting the slope depositional system was dominated by bypass and erosion (Robb et al., 1983; McHugh et al., 1993). Holocene sediments are virtually absent throughout the outer shelf, but the slope and rise are covered by thin, fine-grained pelagic and hemipelagic facies often reworked by mass movement processes (Poag, 1985).

\section{Data and methods}

\subsection{Bathymetric data}

Multibeam bathymetry data used in this study were collected during 26 separate cruises covering approximately $616,000 \mathrm{~km}^{2}$ of the slope and rise between Georges Banks and the Blake Plateau (Fig. 3). All data were referenced to Mean Sea Level (MSL) and were initially gridded to $25-\mathrm{m}$ resolution in $1 \times 1^{\circ}$ tiles. Each tile was smoothed using a Wiener 2-D adaptive noise-removal filter and individual tiles were mosaiced in ArcInfo to create a single bathymetric elevation model at $25-\mathrm{m}$ resolution. This grid was resampled to grid-cell resolution of $100-\mathrm{m}$ resulting in a $386,000-\mathrm{km}^{2}$ subset DEM used for the geomorphic analysis (Fig. 1). Gaps in multibeam coverage in shallow regions ( $<500 \mathrm{~m}$ depths; Fig. 3 ) were merged with data from the 3 arc sec NOAA Coastal Relief Model (NOAA, 2010). Some deep-water regions $\left(<5000 \mathrm{~km}^{2}\right)$ that were not covered by swath bathymetry or the Coastal Relief Model were supplemented with 1 arc min ETOPO-1 bathymetry (Amante and Eakins, 2009).

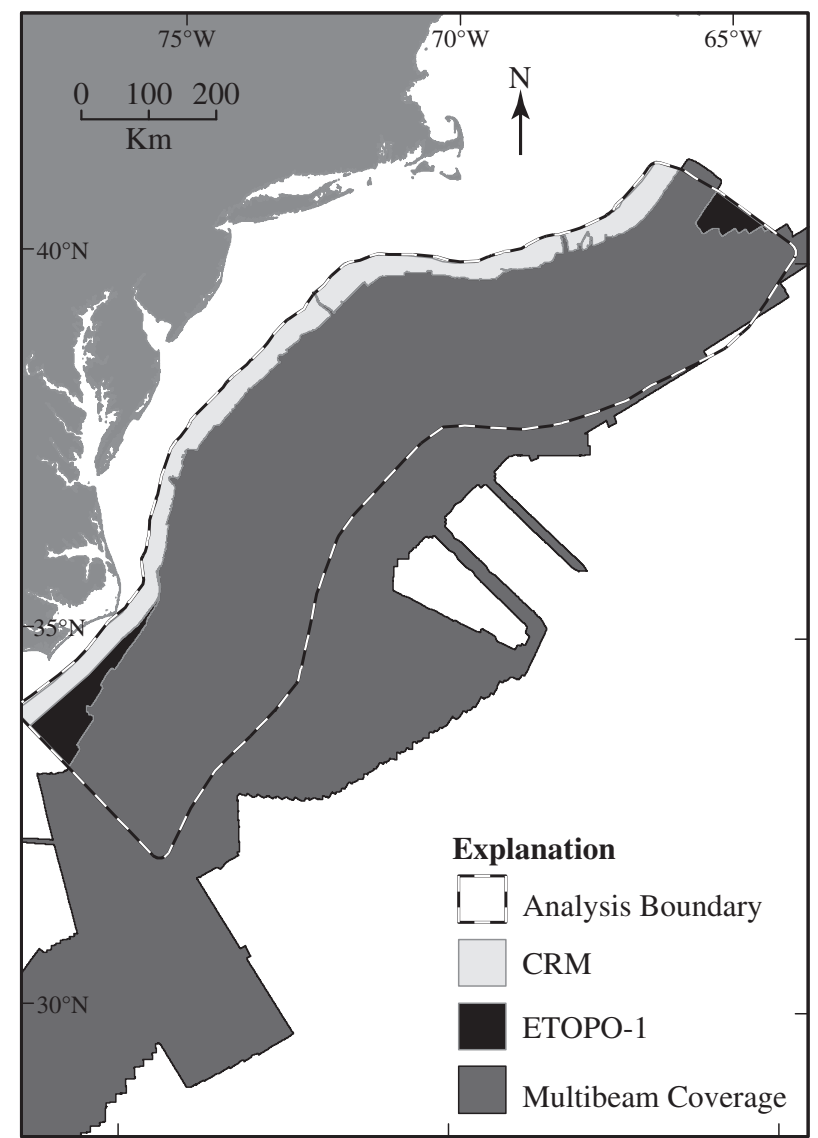

Fig. 3. Geomorphic analysis boundary (Fig. 1). Bathymetric data sources: 3 arc min NOAA coastal relief model (CRM; NOAA, 2010), ETOPO-1 global relief data ( 1 arc min; Amante and Eakins, 2009) and multibeam echosounder mosaic (100-m pixel resolution). CRM and ETOPO-1 data included in the analysis region were used to fill gaps in multibeam bathymetry coverage for water depths shallower than $500 \mathrm{~m}$ and greater than $\sim 5000 \mathrm{~m}$, respectively.

Four derivative grids were produced from the $100-\mathrm{m}$ resolution bathymetric DEM and used in the analysis described in this paper.

1. Seafloor gradient - maximum rate of change between each cell and its eight nearest neighbors (in degrees).

2. Seafloor aspect - steepest downslope direction from each cell to its eight nearest neighbors.

3. Ridge-smoothed surface (RSS) - hypothetical uncanyonized margin. Obtained by interpolating bathymetric control points along canyon interfluves. The RSS preserves the short wavelength shapes of down-slope trending topography located outside of canyons. The interpolation effectively removed - or filled in - canyons and channels preserving the short-wavelength, down-slope oriented morphology as expressed by the inter-canyon ridges (Figs. 4 and 5).

4. Canyon/channel relief - Measure of vertical relief between a given point and the nearest inter-canyon ridge-crest. Obtained by subtracting the $100-\mathrm{m}$ bathymetric surface from the ridgesmoothed surface. Canyon/channel relief was extracted along the trace of each thalweg (Figs. 4 and 5). Canyon relief was not extracted to the south of Cape Hatteras due to incomplete multibeam bathymetry coverage.

\subsection{Bathymetric analysis}

The study region was divided into 21 subsets oriented approximately perpendicular to the local shelf break (Fig. 4). The edges of each subset area were selected along bathymetric divides, often defined by 

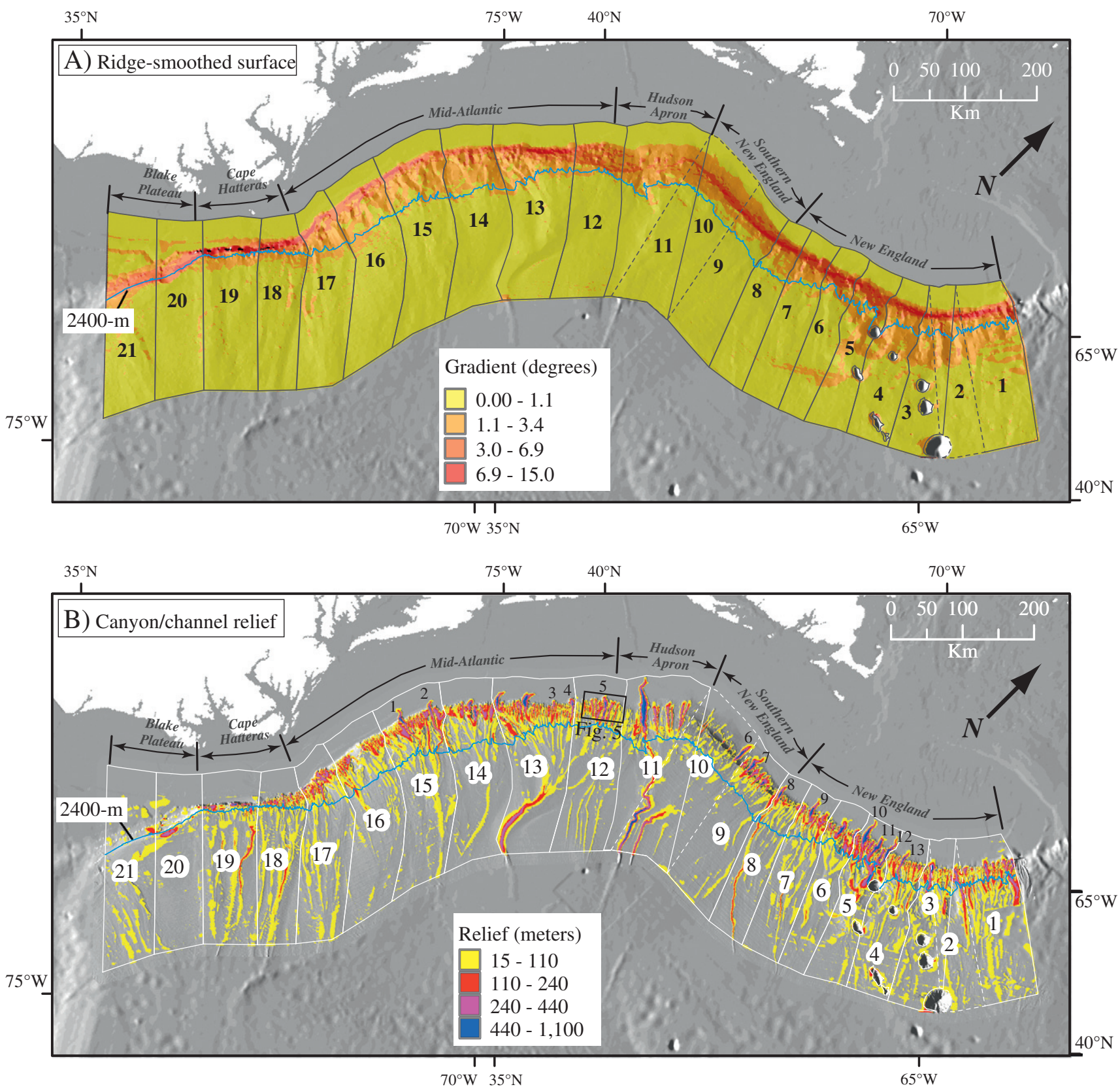

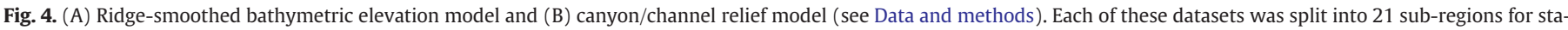

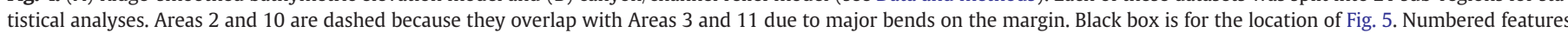

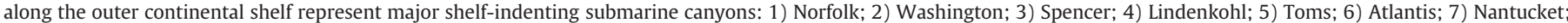
8) Veatch; 9) Hydrographer; 10) Oceanographer; 11) Gilbert; 12) Lydonia; 13) Powell.

morphologic boundaries associated with large shelf-indenting canyons and channels. Areas 1-8 offshore New England are closely spaced because the density of major canyons and hence the along-margin bathymetric variation is expected to be higher than any other region. To the south, along Southern New England and the Mid-Atlantic, major canyon systems are more spread out and selected subsets are wider. Some regions ( 2 and 3, 10 and 11) overlap due to bends in the margin.

We start by assuming that uncanyonized portions of the continental slope and rise (RSS) provide representative morphology of slope progradation by advancing sedimentary clinoforms (Mitchum et al., 1977; Pirmez et al., 1998; O'Grady et al., 2000). In each area, the mean aspect of all RSS grid-cells between the $-60 \mathrm{~m}$ and $-4000 \mathrm{~m}$ isobaths was used as an approximation for down-slope direction. Grid-cells were then windowed such that all cells having aspects outside $\pm 1 / 2 \sigma$ of the mean aspect were excluded. This windowing procedure removes short wavelength, slope-perpendicular topography and artifacts introduced during creation of the RSS (e.g., Supplementary Fig. S1). The remaining grid-cells were binned into 20 -m depth increments between -60 and $-4000 \mathrm{~m}$ and the average gradient was computed within each depth bin for all 21 areas following the approach of O'Grady et al. (2000). Depth-gradient distributions were converted into 2-D profiles of depth versus across-margin distance. The same approach was used to create plots of depth versus average canyon/channel relief. Relief values were extracted along channel thalwegs for Areas 1-18 and averaged within the same 20 -m depth-bins. Note only the slope confined ("slope soured") canyons were used in the analysis because shelf-indenting ("shelf sourced") canyons have generally experienced numerous cut and fill cycles, in which case the geological significance 

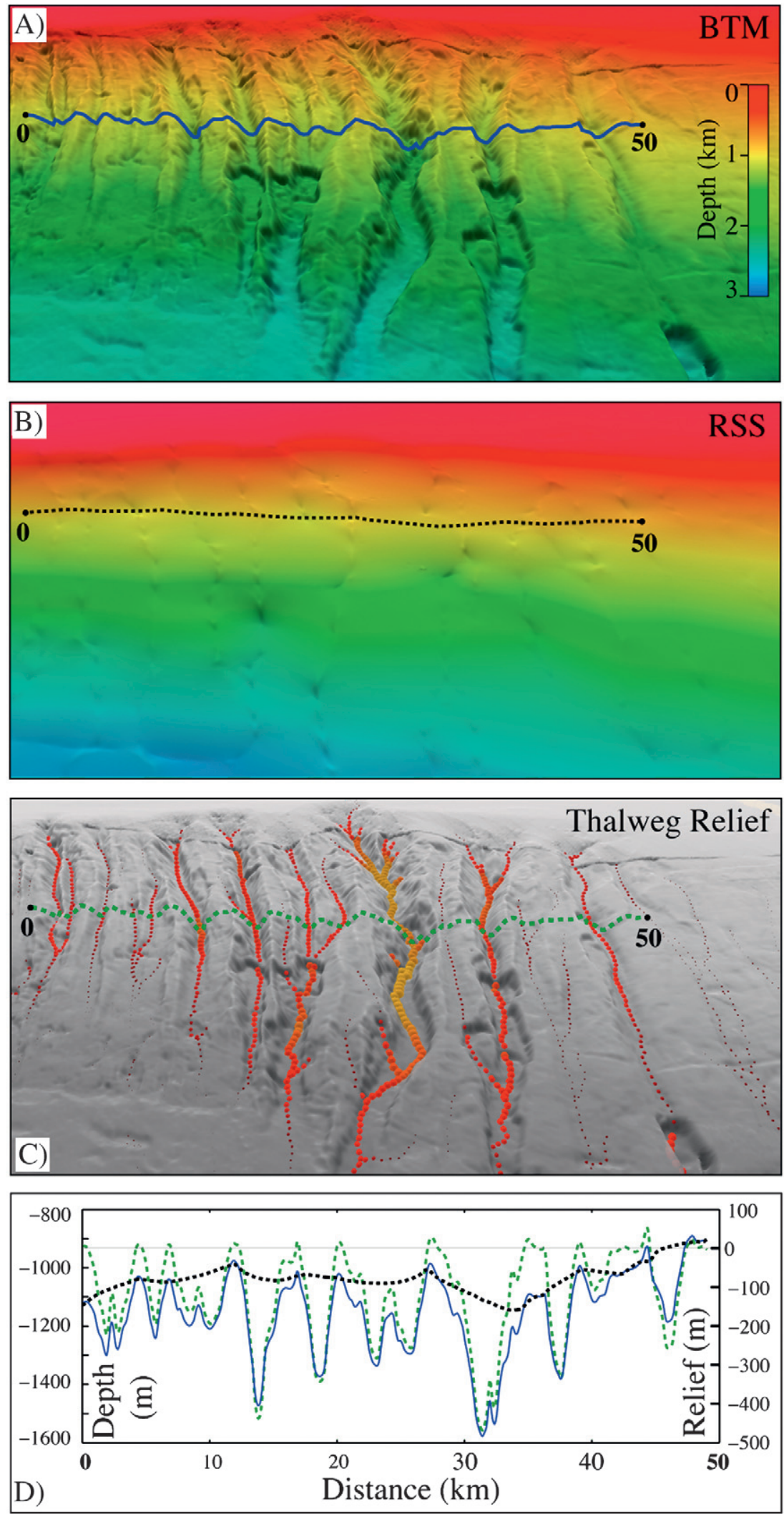

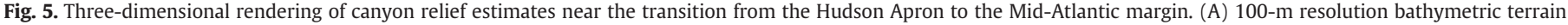

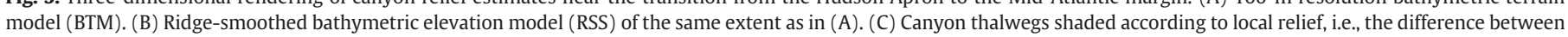

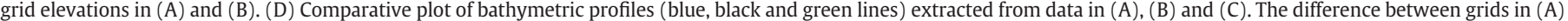

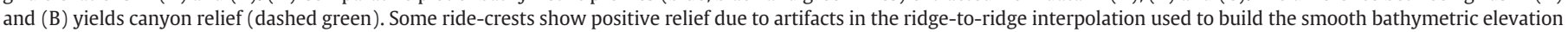
model. 
of canyon relief is more difficult to constrain. For example, Hudson Canyon and other major canyon systems were excluded from the depth-relief distributions.

Next, following the approach described by O'Grady et al. (2000) basic statistics were computed for the bathymetry of the slope (Table 1A) and rise (Table 1B). The statistical similarities between gradient-depth distributions in each area were analyzed using maximum likelihood factor analysis (Harman, 1976; Reyment and Joreskog, 1993). Groupings of similar slope morphology (0-2400 m depths) were selected by comparing factor loadings for the gradientdepth distributions with the maximum gradient and depth of maximum gradient in each area (Table 1A). The groupings and their associated depth-relief distributions were examined in conjunction with USGS and WesternGeco seismic reflection profiles (Schlee and Poag, 1980; Poag, 1985; Klitgord et al., 1994; Hutchinson et al., 1996; Flores et al., 2011). At least one seismic reflection profile crosses

Table 1

Summary statistics for each area of the study region and split according to seafloor depth: outer continental shelf and slope (A); continental rise (B). Similarity groupings were determined based on statistical similarities between depth-gradient distributions for each area (see text). Average gradient is the average over the entire area and depth interval; max gradient, depth of max gradient, max relief and depth of max relief are taken from the depth-gradient distribution functions and therefore do not represent absolute maxima.

\begin{tabular}{llllllll}
\hline Area & $\begin{array}{l}\text { Similarity } \\
\text { grouping }\end{array}$ & $\begin{array}{l}\text { Ave. } \\
\text { gradient }\end{array}$ & $\begin{array}{l}\text { Max } \\
\text { gradient }\end{array}$ & $\begin{array}{l}\text { Depth of max } \\
\text { gradient } \\
(\mathrm{m})\end{array}$ & $\begin{array}{l}\text { Ave. } \\
\text { relief } \\
(\mathrm{m})\end{array}$ & $\begin{array}{l}\text { Max } \\
\text { relief } \\
(\mathrm{m})\end{array}$ & $\begin{array}{l}\text { Depth of } \\
\text { max relief }\end{array}$ \\
& & & & $(\mathrm{m})$
\end{tabular}

\begin{tabular}{|c|c|c|c|c|c|c|c|}
\hline \multicolumn{8}{|c|}{ A: Continental slope (60-2400 m depth) } \\
\hline 1 & 1 & 5.3 & 9.1 & -1025 & 111 & 215 & -1305 \\
\hline 2 & 1 & 4.7 & 9.5 & -945 & 152 & 217 & -1125 \\
\hline 3 & 1 & 4.7 & 9.5 & -925 & 129 & 188 & -865 \\
\hline 4 & 1 & 4.1 & 7.4 & -865 & 137 & 204 & -845 \\
\hline 5 & 1 & 3.8 & 6.2 & -725 & 282 & 421 & -1325 \\
\hline 6 & 1 & 4.9 & 8.6 & -965 & 185 & 328 & -745 \\
\hline 7 & 1 & 4.0 & 7.1 & -845 & 189 & 352 & -345 \\
\hline 8 & 1 & 4.1 & 8.4 & -985 & 94 & 199 & -765 \\
\hline 9 & 2 & 3.6 & 7.2 & -1405 & 196 & 415 & -1085 \\
\hline 10 & 2 & 3.0 & 5.9 & -1225 & 56 & 121 & -245 \\
\hline 11 & 3 & 2.5 & 3.5 & -1765 & 111 & 214 & -425 \\
\hline 12 & 3 & 3.2 & 4.1 & -1865 & 126 & 192 & -405 \\
\hline 13 & 4 & 4.2 & 7.2 & -725 & 144 & 233 & -285 \\
\hline 14 & 4 & 2.9 & 6.3 & -505 & 144 & 279 & -985 \\
\hline 15 & 4 & 3.2 & 6.4 & -505 & 148 & 241 & -985 \\
\hline 16 & 4 & 3.7 & 7.0 & -465 & 115 & 242 & -985 \\
\hline 17 & 4 & 4.3 & 7.7 & -605 & 165 & 298 & -1425 \\
\hline 18 & 5 & 7.7 & 11.3 & -1145 & 168 & 298 & -345 \\
\hline 19 & 5 & 8.5 & 13.0 & -1125 & - & - & - \\
\hline 20 & 6 & 5.4 & 7.8 & -945 & - & - & - \\
\hline 21 & 6 & 4.0 & 8.6 & -2265 & - & - & - \\
\hline \multicolumn{8}{|c|}{ B: Continental rise (2400-4000 m depth) } \\
\hline 1 & 1 & 1.3 & 2.1 & -2405 & 187 & 311 & -3693 \\
\hline 2 & 1 & 1.5 & 2.3 & -3265 & 76 & 356 & -2402 \\
\hline 3 & 1 & 1.6 & 2.2 & -3085 & 52 & 283 & -2966 \\
\hline 4 & 1 & 1.6 & 2.3 & -2625 & 43 & 220 & -2405 \\
\hline 5 & 1 & 1.5 & 2.3 & -3465 & 132 & 580 & -2633 \\
\hline 6 & 1 & 0.9 & 1.7 & -2405 & 33 & 145 & -2425 \\
\hline 7 & 1 & 0.8 & 1.1 & -2425 & 51 & 254 & -3525 \\
\hline 8 & 1 & 0.7 & 1.0 & -2625 & 57 & 257 & -3450 \\
\hline 9 & 2 & 0.6 & 1.0 & -3865 & 19 & 78 & -2685 \\
\hline 10 & 2 & 0.5 & 0.8 & -3385 & 43 & 355 & -3056 \\
\hline 11 & 3 & 0.6 & 0.8 & -2405 & 49 & 355 & -3057 \\
\hline 12 & 3 & 0.7 & 1.1 & -2405 & 32 & 142 & -3085 \\
\hline 13 & 4 & 0.8 & 3.5 & -3905 & 58 & 441 & -3376 \\
\hline 14 & 4 & 0.6 & 1.3 & -2465 & 24 & 132 & -3405 \\
\hline 15 & 4 & 0.6 & 1.2 & -2405 & 32 & 148 & -2505 \\
\hline 16 & 4 & 0.8 & 1.1 & -2405 & 18 & 138 & -2403 \\
\hline 17 & 4 & 0.9 & 1.3 & -2485 & 25 & 147 & -2424 \\
\hline 18 & 5 & 0.9 & 2.4 & -2405 & 48 & 170 & -3610 \\
\hline 19 & 5 & 1.1 & 3.6 & -2405 & $\mathrm{~N} / \mathrm{A}$ & $\mathrm{N} / \mathrm{A}$ & $\mathrm{N} / \mathrm{A}$ \\
\hline 20 & 6 & 1.6 & 6.4 & -2405 & $\mathrm{~N} / \mathrm{A}$ & $\mathrm{N} / \mathrm{A}$ & $\mathrm{N} / \mathrm{A}$ \\
\hline 21 & 6 & 1.7 & 5.2 & -2405 & $\mathrm{~N} / \mathrm{A}$ & $\mathrm{N} / \mathrm{A}$ & $\mathrm{N} / \mathrm{A}$ \\
\hline
\end{tabular}

each of the 21 analysis areas. The thickness and approximate age of allostratigraphic (unconformity-bounded) units have been determined from seismostratigraphic analysis and correlation to drill holes, dredge samples from the walls of submarine canyons and exposed outcrops on the slope (Schlee et al., 1976, 1979; Valentine et al., 1980; Robb et al., 1983; Poag, 1985, 1992; Dillon and Popenoe, 1988; Grow et al., 1988; Klitgord et al., 1994).

\section{Results}

Factor analysis applied to gradient-depth distributions indicates that $64 \%$ of total variance between all twenty-one areas can be related to two common factors. We plot factor-2 loadings versus the associated maximum gradient for each area (Fig. 6; O'Grady et al., 2000). Groupings were selected based on relative clustering of points shown in Fig. 6 and similarities in the depth of maximum average slope gradient for each area (Table 1A). We find six potential groupings that follow a progression of changing slope morphology from north to south (Fig. 7): Group-1 includes each of the areas (1-8) off New England and Georges Bank; Group-2 (Areas 9 and 10) and Group-3 (areas 11 and 12) comprise southern New England and the Hudson Apron, respectively; Group-4 (areas 13-17) is along the Mid-Atlantic; Groups 5 (areas 18 and 19) and 6 (areas 20 and 21) cover the region south of Cape Hatteras along the region seaward of the Blake Plateau.

\subsection{New England margin (Group-1; Areas 1-8)}

The New England margin has relatively high average continental slope $\left(4.5^{\circ} \pm 0.5^{\circ}\right)$ and rise $\left(1.2^{\circ} \pm 0.4^{\circ}\right)$ gradients, although the rise shows considerable variation (e.g., Areas 1-4 versus Areas 5-8; Fig. 7, Supplementary Fig. S2). The depth-distance profiles have rounded shelf-breaks and upper slopes (upper $700 \mathrm{~m}$ ), but steep $\left(7^{\circ}-10^{\circ}\right)$, concave middle (700-1400 $\mathrm{m}$ depths) and lower slopes (1400-2100 $\mathrm{m}$ depths) that reach maximum steepness between $\sim 500$ and $1600 \mathrm{~m}$ depths (Table $1 \mathrm{~A}$ and Figs. 7-9). The continental slopes have maximum canyon relief concentrated at approximately the same depth interval as the maximum gradient (Fig. 7 and Table 1A; Supplementary Figs. S3-S6). Wide, steep-walled submarine canyons and channels (Figs. 4B and 8A) produce the highest average canyon relief on the USAM continental slope (160 m) and rise (79 $\mathrm{m})$ within the entire study area. The continental slope grades into a

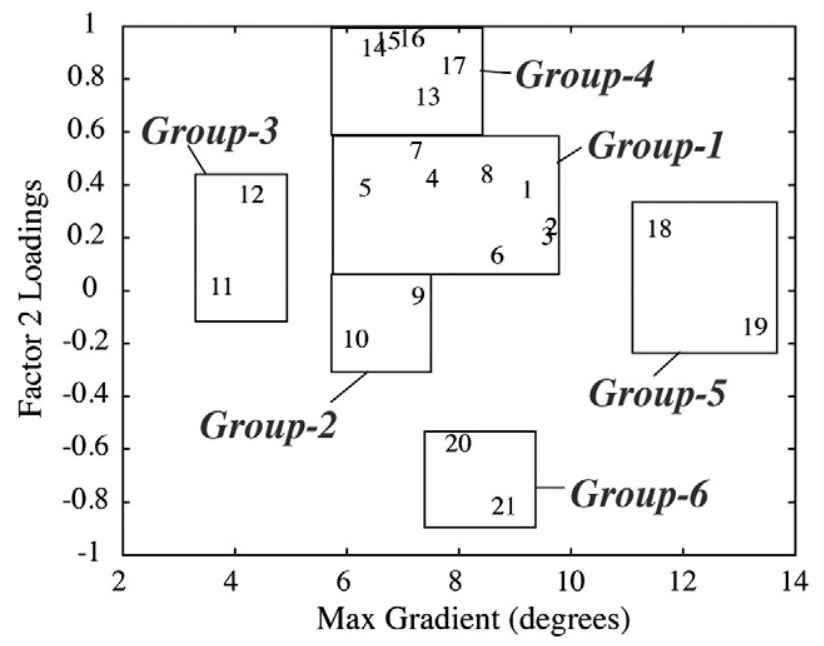

Fig. 6. Factor-2 loadings versus maximum average gradient for each area (following O'Grady et al., 2000). Six general groupings are identified by comparing this figure with the depth of maximum gradient for each area (Table 1 ). 
Depth-Gradient Distributions

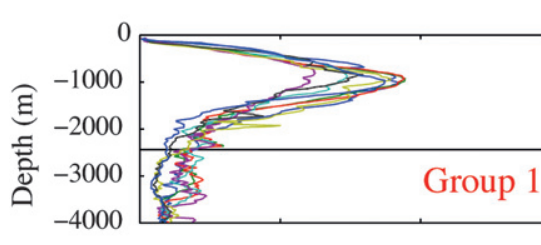

Mean Gradient (Degrees)
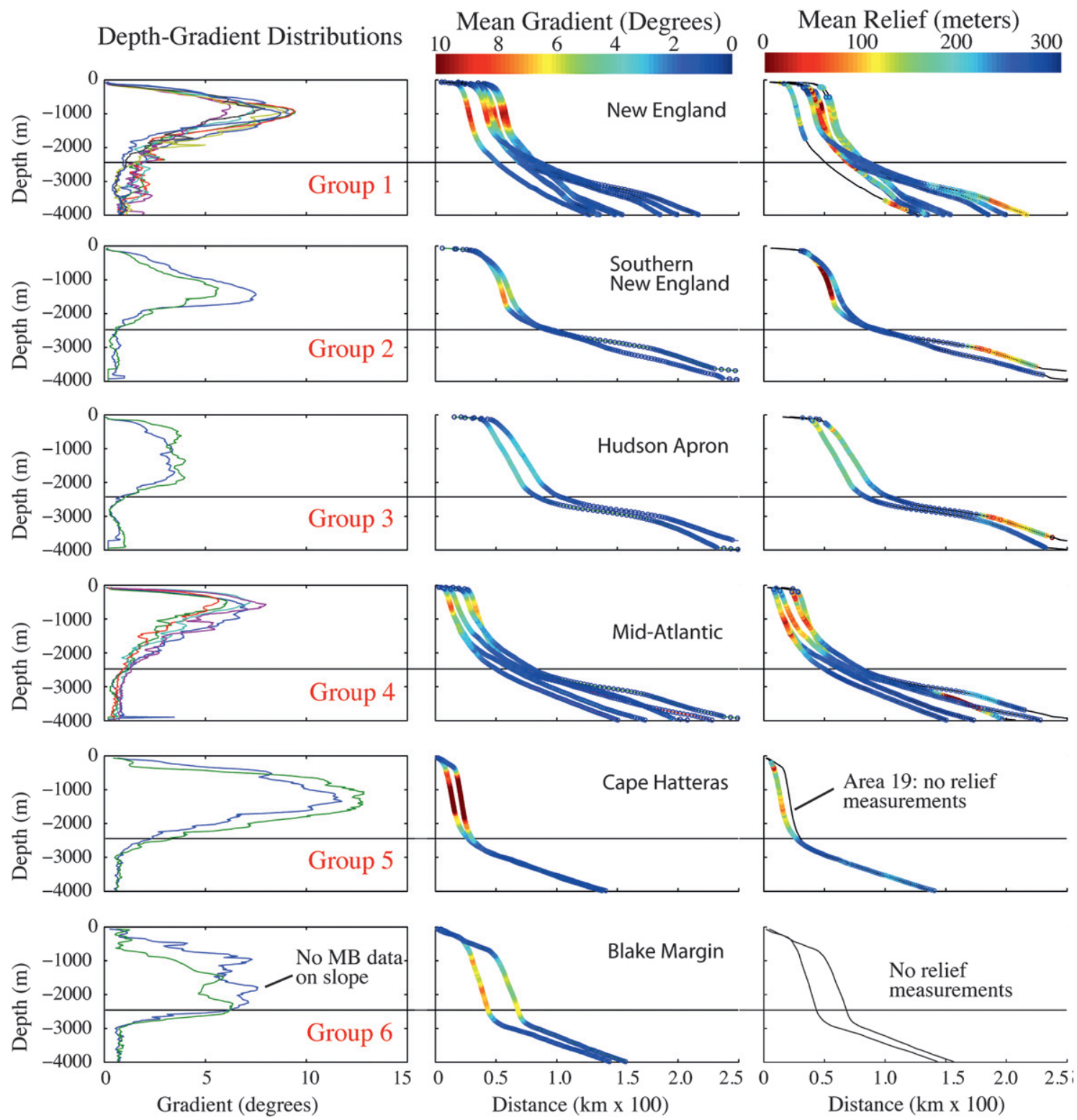

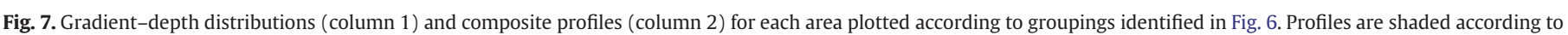
the average gradient (column 2) and relief (column 3) at each depth interval. See Supplementary Figs. S2-S6 area-by-area distributions of depth, gradient and relief.

relatively steeply inclined upper rise (Table 1B; Fig. 8). Area 8 marks the beginning of a $40^{\circ}$ westward bend in the margin and the transition to Group-2.

The steepest segment of the continental slope of Group-1 is approximately coincident with the seaward edge of the buried Mesozoic reef bank (Table 1; Fig. 9A). Although prograding Cenozoic shelf sequences overlie the buried reef edge, they have been truncated along the slope-face. A seaward thickening wedge of Quaternaryaged sediment is exposed at the seafloor, showing widespread incision by submarine canyons and truncation along much of the upper and middle slope (Figs. 8A, 9A and 10A). In places, the Quaternary sediment wedge is more than $300-\mathrm{m}$ thick and appears to define the position and shape of the modern shelf break, but in other places appears to mimic the curvature of the underlying strata. The thick wedge of Quaternary fan/apron material on the upper rise onlaps and in places blankets the seaward facing reef bank. The wedge is heavily channelized, terraced and scarred by mass movement processes (e.g., Chaytor et al., 2012; Figs. 8A, 9A and 10A).
Relief of slope-sourced canyons appears to vary according to the thickness of Quaternary sediment on the continental slope (Figs. 9A and 10A): a thin Quaternary package is associated with parallel, closely spaced and low relief canyons, whereas widely spaced canyons and dendritic networks are associated with thicker Quaternary sediments. Relief of slope-sourced canyons essentially disappears on the rise. The major shelf-sourced canyons have greater relief than slope-sourced canyons and usually cut through pre-Quaternary strata. On the rise, they become broad channel valleys that are encased in Quaternary-aged fan-apron packages and channel valleys contain narrow, steep walled and often tightly meandering inner-thalwegs.

4.2. Southern New England and the Hudson Apron (Groups 2 and 3; Areas 9-12)

Slopes along southern New England and the Hudson Apron are assigned to Group-2 and Group-3 (Figs. 6 and 7). In this the continental slopes are $30-50 \mathrm{~km}$ wide and have convex curvature extending 

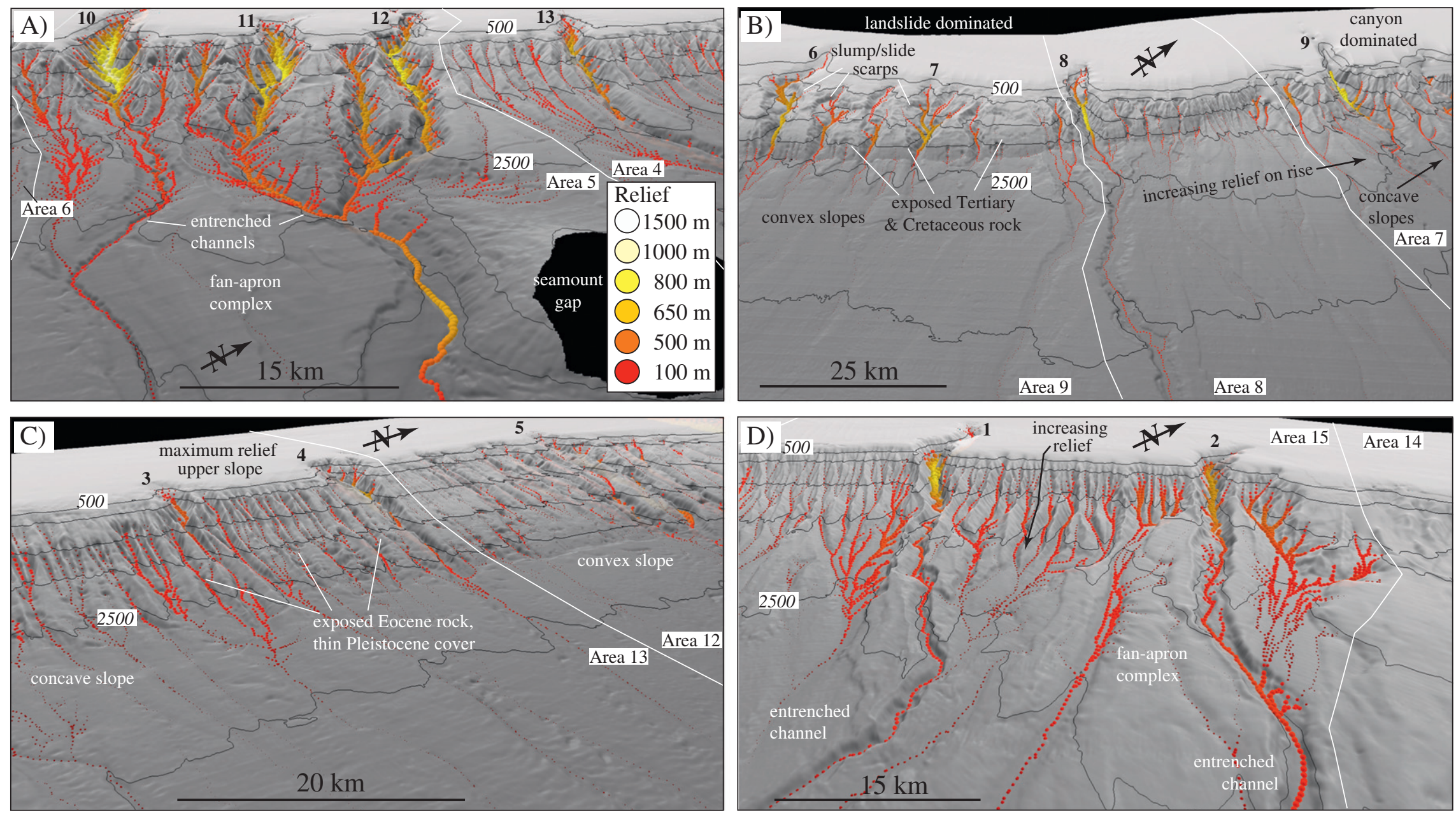

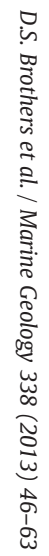

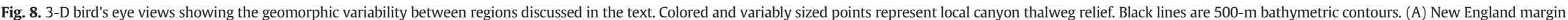

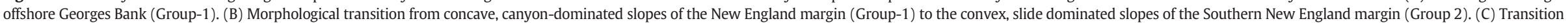

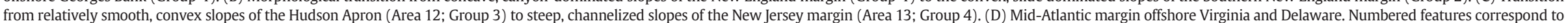
major shelf-indenting submarine canyons also shown in Fig. 4. Vertical exaggeration is $5 \times$. 
down to $1800 \mathrm{~m}$ depth (Figs. 8 and 9), markedly different from the regions to the north and south. The outer shelf and upper slope of both groups are relatively broad. The maximum steepness occurs along the lower slope, between depths of 1225-1405 m for Group-2 and 1765-1865 $\mathrm{m}$ for Group-3 (Table 1). However, the middle slope of both groups is at nearly constant $3^{\circ}-4^{\circ}$ (Fig. 7). The continental slope of Group-2 is highly convex, but Group-3 is more subtle/nearly linear.

Besides a few widely spaced, shelf-sourced canyons, Groups 2 and 3 have relatively low average canyon relief (Figs. 8 and 9B). No systematic relationship between canyon relief and slope gradient is observed (Fig. 8; Supplementary Figs. S2-S4). The large canyons of Area 9 (e.g., Atlantis, Nantucket, Alvin) are wide $(5-7 \mathrm{~km})$, have blocky walls and cut more than $500 \mathrm{~m}$ into exposed Tertiary and Cenozoic strata (Fig. 9B; O'Leary, 1986). Canyons to the northeast of Hudson Canyon occur in pairs every $20-30 \mathrm{~km}$ and are separated by broad, inter-canyon plains. They are straight with very few trubitary canyons/gullies, but contain numerous collapse features along their side-walls (Fig. 8B; O'Leary, 1986). The slope and rise of Group-2 are covered by landslide scars ( $<100 \mathrm{~m}$ high) and have abundant evidence for mass wasting processes (Flores et al., 2011; Fig. 9B).

Interpreted seismic reflection profiles also show distinctly different stratal architecture beneath Groups 2 and 3 than areas to the north and south (Figs. 9B, 10B and 11). The Mesozoic reef bank is located beneath the slope, but relief across its face is small relative to Group-1 and it is buried by thick, prograding layers of Late Cretaceous and Cenozoic age sediments. Tertiary layers beneath the slope and rise have been truncated along regional unconformity surfaces (Fig. 11B; Mountain and Tucholke, 1985; Poag, 1992; Schlee et al., 1979).

Quaternary slope strata of Group-2 are truncated by scarps and unconformities (Fig. 11A), so stratigraphic correlation from the slope to the rise is not possible. A broad ramp separates the lower slope from the upper rise (Fig. 10B; Schlee et al., 1979). An along-strike bathymetric lineament roughly defines the upper and lower limits of the ramp (Fig. 9B). In cross-section, the ramp consists of stacked, upslope thickening packages of Quaternary sediment and individual layers are observed to onlap a steep, lower-slope erosional unconformity (Fig. 11A). The ramp is less apparent in Group-3, closer to Hudson Canyon, and relief across the base-of-slope unconformity is reduced. The degree of mass wasting along the slope of Group-3 diminishes relative to Group-2; shallow slope strata show seaward progradation and strata can be traced from the upper slope to the rise (Fig. 11B). The southern part of Area 12 begins to transition from the relaxed, convex slope profiles of Group-3 to the steep, concave slopes of Group-4 (Fig. 7). As noted by Goff (2001), canyon density and relief on the slope increase abruptly at the southeastern edge of the Hudson Apron (Figs. 8C, 9B and 10B).

\subsection{Middle Atlantic (Group-4; Areas 13-17)}

An abrupt shelf-break, narrow $(<20 \mathrm{~km})$ slope, and relatively steep upper slope distinguish the middle Atlantic from other regions (Figs. 7, 8, 12). Although the average gradient of the slope $\left(3.7^{\circ} \pm\right.$ $\left.0.4^{\circ}\right)$ and rise $\left(0.7^{\circ} \pm 0.1^{\circ}\right)$ is relatively moderate, high gradients between $6.3^{\circ}$ and $7.7^{\circ}$ are found between depths of 465-605 $\mathrm{m}$ along the upper slope (Table 1). Averaged depth-distance profiles have nearly angular shelf-breaks, narrow ( $15 \mathrm{~km}$ width), concave slopes, and gradual transitions between the lower slope and upper rise. Most shelf-sourced canyons have well-developed inner-thalwegs along canyon valleys of the rise (Fig. 8D) and contain the highest relief of the slope and rise. In general, relief of slope-sourced canyons increases downslope to a maximum at depths $>1000 \mathrm{~m}$ (Table 1; Figs. 8, 9D; Supplementary Fig. S4). Areas 13 and 14 have local highs in relief along the outer shelf and upper slope. With the exception of the Currituck landslide scar (Fig. 10C), evidence for large-scale mass wasting and associated deposits is concentrated on the lower slope and upper rise (e.g., Fig. 12B; Twichell et al., 2009).

Seismic profiles show at least three distinguishing features in Areas 13-17: first, the Mesozoic reef is buried beneath the upper rise, more than $20 \mathrm{~km}$ seaward of the modern shelf break, and appears to have been down-faulted (Schlee et al., 1979). Second, a massive (up to $1 \mathrm{~km}$ thick) seaward thickening wedge of Middle Miocene sedimentary sequences underlies the shelf-break and the middle to upper slope. The truncated seaward face of the wedge coincides with steep gradients of the upper slope (Fig. 12). Third, shallowly buried and/or outcrops of indurated Eocene chalks and marls (Robb et al., 1983; Pratson and Coakley, 1996) underlie gentler gradients of the lower slope and the change in gradient from the middle to lower slope closely aligns with the contact between the Middle Miocene sequences and the Eocene chalks (Fig. 12).

As with the New England margin, the spacing and relief of slope-sourced canyons along the Mid-Atlantic appear related to the thickness of Quaternary sediments (Fig. 10C). For Areas 14-17, relief increases along the middle and lower slope as thickness of Quaternaryaged fan-apron complexes increases (Table 1; Figs. 8, 9D; Supplementary Fig. S4). The local highs in relief of Areas 13 and 14 along the outer shelf and upper slope may be caused by canyons that extend a small distance onto the shelf (Fig. 8C), biasing the average relief calculation near the shelf edge, but the highs also coincide with Pleistocene depocenters along the outer shelf and upper slope (Pratson et al., 1994). Slope-sourced canyons of Area 13 are parallel, closely spaced $(<3 \mathrm{~km}$ apart) and have relatively low relief where Quaternary sediment either is thin or missing (Figs. 8C, 10B, 12A).

\subsection{Cape Hatteras and the Blake Plateau (Groups 5 and 6; Areas 18-21)}

Availability of multibeam bathymetry data to the south of Cape Hatteras is limited (Fig. 3); therefore, analysis of Groups 5 and 6 is shown only to illustrate the dramatic morphological changes that occur in this region (Fig. 8). The Cape Hatteras margin takes a $35^{\circ}$ westward bend and is characterized by steep slopes $\left(>10^{\circ}\right)$ that extend to greater depths than other groups. Estimates of canyon/ channel relief on the slope and rise are relatively low. Several channels extend hundreds of kilometers across the rise. Numerous landslide scars, mass transport deposits and evidence for strong contour currents are observed along the upper rise. Previous interpretations of seismic reflection profiles suggested the slope off Cape Hatteras has experienced more erosion and landward retreat than any of the areas to the north (Schlee et al., 1979).

\section{Discussion}

The statistical groupings can be used to support a categorization of the margin based on Quaternary sedimentary processes: glacial dominated margin off Georges Bank and Southern New England (Groups 1-3), river and fan-delta dominated, but likely glacially-influenced, region between the Hudson Apron and Cape Hatteras (Groups 3 and 4) and the erosional, carbonate platform to the south of Cape Hatteras (Groups 5 and 6). Consequently, our discussion is primarily aimed at understanding the interplay between Quaternary sedimentary processes and inherited, pre-Quaternary margin physiography/antecedent geology.

The rounded shelf-edge of the New England and Southern New England margins may be due to their proximity to a pro-glacial forebulge that formed during continental glaciations (Peltier, 1996). The shelf-edge may have been located in relatively shallow water depths during much of the subsequent sea level rise and experienced greater wave-driven advection (Fig. 2B). In contrast, the angular shelf-edge of the Mid-Atlantic margin implies that the 
transition between advection-dominated and gravity driven transport regimes of the outer shelf and upper slope is more abrupt (Fig. 2A).
Depending on the location, the average gradient of the lower slope/ upper rise appears to be either inherited from buried, antecedent geology (e.g., Fig. 12) or controlled by the accumulation of onlapping
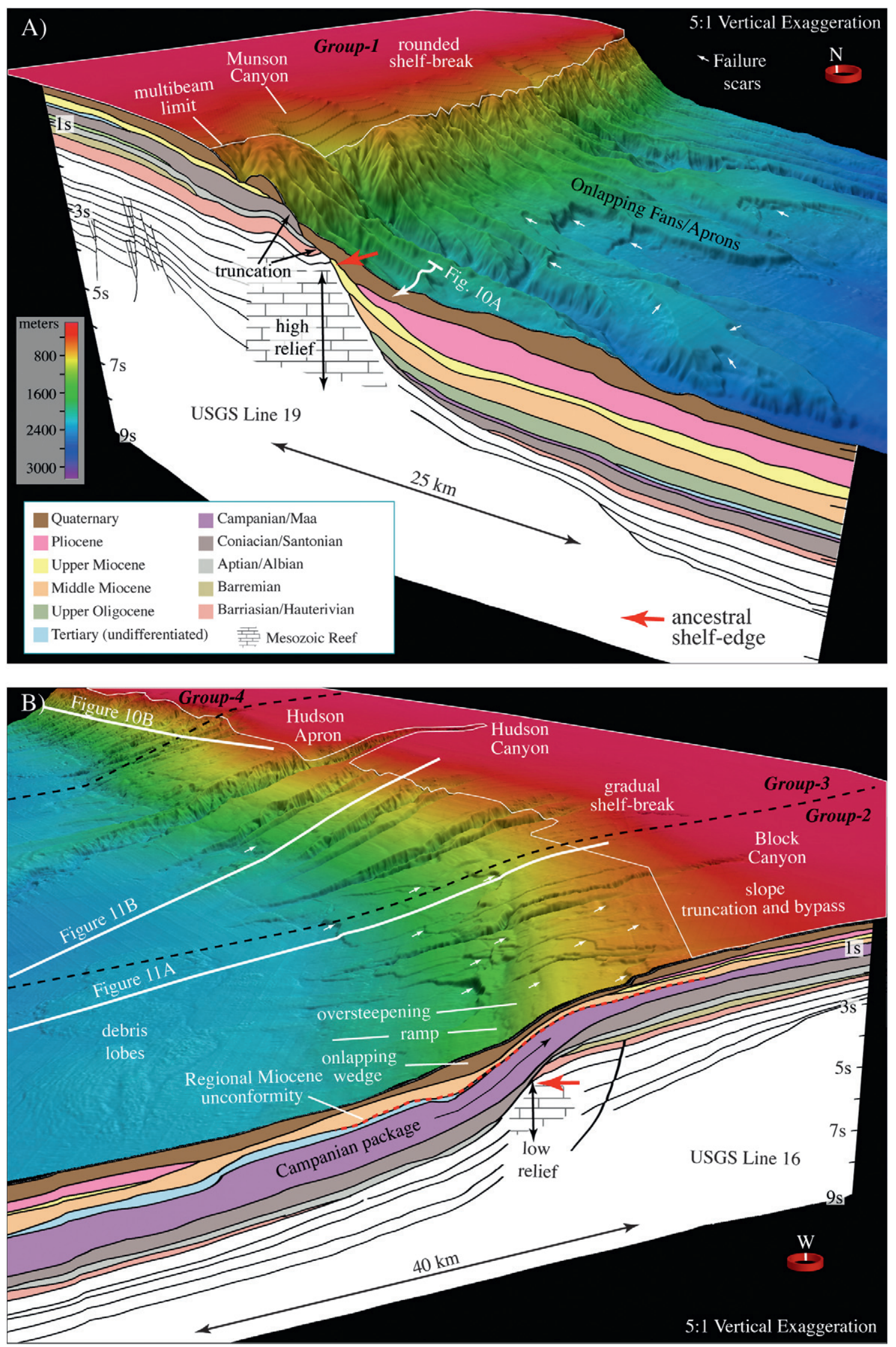
wedges of Plio-Pliestocene fan-apron deposits (e.g., Fig. 9). Average canyon relief versus average slope gradient is plotted at five depth intervals across Areas 1-18 (Fig. 13). Points appear random from the shelf edge to depth of $1500 \mathrm{~m}$, suggesting that at the margin-scale, gradient is not the primary control on canyon incision of the upper slope, but that other factors (e.g., pre-existing physiography, lithology and sediment shear strength) are more important. In contrast, gradient and relief are positively correlated at depths between 2000 and $3000 \mathrm{~m}$. We propose that the distribution of canyon relief on the continental rise may be a proxy for the thickness of less resistant, Quaternary-aged fan/apron packages.

O'Grady et al. (2000) used global, low-resolution (2 arc min) bathymetric data to characterize the morphologoy of passive, siliciclastic margins. They identified five primary patterns, three of which may be recognized along the USAM. A distinctive peak in the depth-gradient distributions characterizes Type-II margins of O'Grady and continental slopes are associated with smooth bathymetry, high sediment input and prograding strata. Type-III margins contain relatively high maximum gradients, lack a well-defined peak in depth-gradient distributions, but contain a high degree of gradient variability due to canyonization and truncation of the underlying strata. This pattern includes the recently glaciated margins of the North Atlantic basin. Lastly, Type-IV margins contain steep slopes that maintain relatively constant gradient down to great depths and display relatively high canyonization.

The majority ( $>60 \%$ ) of all siliclastic passive margins are classified as either Type-II or Type-III (O'Grady et al., 2000). One-to-one comparisons between our results and those of O'Grady et al. (2000) are not straightforward because the gradient and canyon relief distributions from our analyses are significantly different due to the higher resolution bathymetric data used. Regardless, the majority of areas along the USAM appear to fall somewhere between Types II and III. Groups 2 and 3 (Southern New England and the Hudson Apron) display the same general shape as O'Grady's Type-III margins; however, these groups also contain the lowest canyon relief and display progradational stratal architecture more similar to O'Grady's Type-II margins. Although distributions for the New England (Group-1) and Mid-Atlantic (Group-4) margins appear most similar to O'Grady's Type-II margins, both regions are characterized by pervasive canyonization and truncation of underlying slope strata. Perhaps O'Grady's gradient distributions for the New Jersey margin are based mostly on data from the Hudson Apron and were biased by the presence of the Hudson Canyon, which was excluded from our depth-relief distributions. Finally, Groups 5 and 6 have similar morphological character to O'Grady's Type-IV margins. The following sections provide detailed discussion of each morphological grouping along the USAM.

\subsection{New England margin (Group-1; Areas 1-8)}

The New England margin has a rounded shelf-edge characteristic of a sigmoidal profile (Fig. 14B). During the Pleistocene, the edge of the Laurentian ice sheet extended across parts of the New England shelf Pratt, 1969; Oldale, 1992. Glacial outwash transported large volumes of sediment across the shelf and slope leaving behind a relatively thick shelf-edge sediment wedge, but also an onlapping prism of slope-front fill beneath the upper continental rise (Emery and Uchupi, 1965; Pratt and Schlee, 1969; Austin et al., 1980; Poag, 1982; Uchupi and Oldale, 1994). Turbulent meltwater pulses may be partially responsible for the high relief of the upper slope and relatively high density of shelf-indenting canyons along the New England margin. Proximal, high-energy outwash pulses transported sandy sediment through outer shelf conduits (McHugh and Olson, 2002), which may have been linked to shelf-edge and upper slope canyons.

The landward shift in the modern shelf-edge has been only a few $\mathrm{km}$ relative to the seaward edge of the Mesozoic reef bank (Schlee et al., 1979). The steep reef front appears to control the location of the rollover point of prograding Cenozoic shelf-edge sediment sequences (Fig. 14D). The near coincidence of the modern day and ancestral shelf edges is due to lower long-term subsidence in this region (Steckler et al., 1988), allowing the relief across the reef-edge to remain high relative to that of the Mid-Atlantic margin. The slope steepness, canyon density, truncation of Quaternary packages and the massive accumulation of onlapping fan-apron complexes on the rise all suggest the slope has been a zone of sediment bypass since formation of the Mesozoic escarpment (Schlee et al., 1979, 1985; Austin et al., 1980; Poag, 1992; McHugh et al., 2002). Thick Pleistocene fan-apron sequences onlap the lower slope and have reduced, but not graded, the preexisting relief across the seaward face of the Mesozoic shelf-edge. Given the current configuration, overall slope progradation is unlikely until the inherited, high-gradient section of the mid-slope is reduced by either erosion or by aggradation of fanapron sequences along the lower slope and upper rise (see model in Fig. 2).

\subsection{Southern New England and the Hudson Apron (Groups 2-3; Areas} 9-12)

Wide, convex slope profiles of Groups 2 and 3 represent the sigmoidal end-members (Fig. 14C,E). The sigmoidal slope of Group-2 is largely a function of inherited physiography rather than Quaternary slope deposition. The modern seafloor roughly mimics the upper boundary of late-Cretaceous strata and a pronounced erosional unconformity exposed along the middle and lower slope (e.g., Fig. 11A; Mountain and Tucholke, 1985). Strong boundary currents during the Miocene eroded the lower slope of Group-2, leading to oversteepening, retrograde failures and mass transport deposition on the rise. The ramp that covers the slope/rise transition in Group-2 is composed of stacked, upslope thickening Quaternary sediment packages that onlap the steep, base-of-slope. The ramp is most likely an accumulation of mass flow deposits that is gradually burying and grading the relief across the unconformity surface. In contrast, the unconformity is less pronounced beneath the Group 3 (Fig. 11B). Pleistocene beds are mostly parallel and conformable from the upper slope to the rise, suggesting that gently inclined, pre-Quaternary bathymetry of the slope may have allowed Pleistocene sediment to settle and accumulate.

Despite having relatively gentle slope gradients, limited canyonization, and high concentration of slope failures, there is little evidence to suggest that Groups 2 and 3 had significantly higher Quaternary sediment flux than Groups 1 and 4. Pre-existing

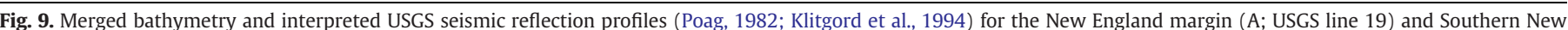

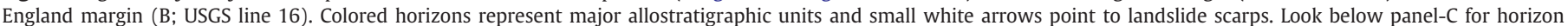

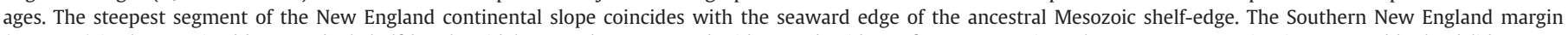

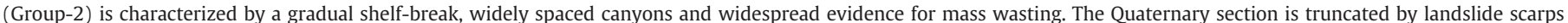

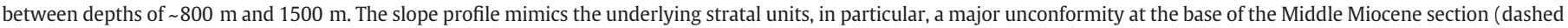

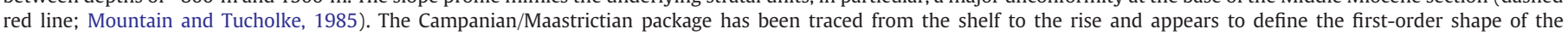
modern-day continental slope.
} 

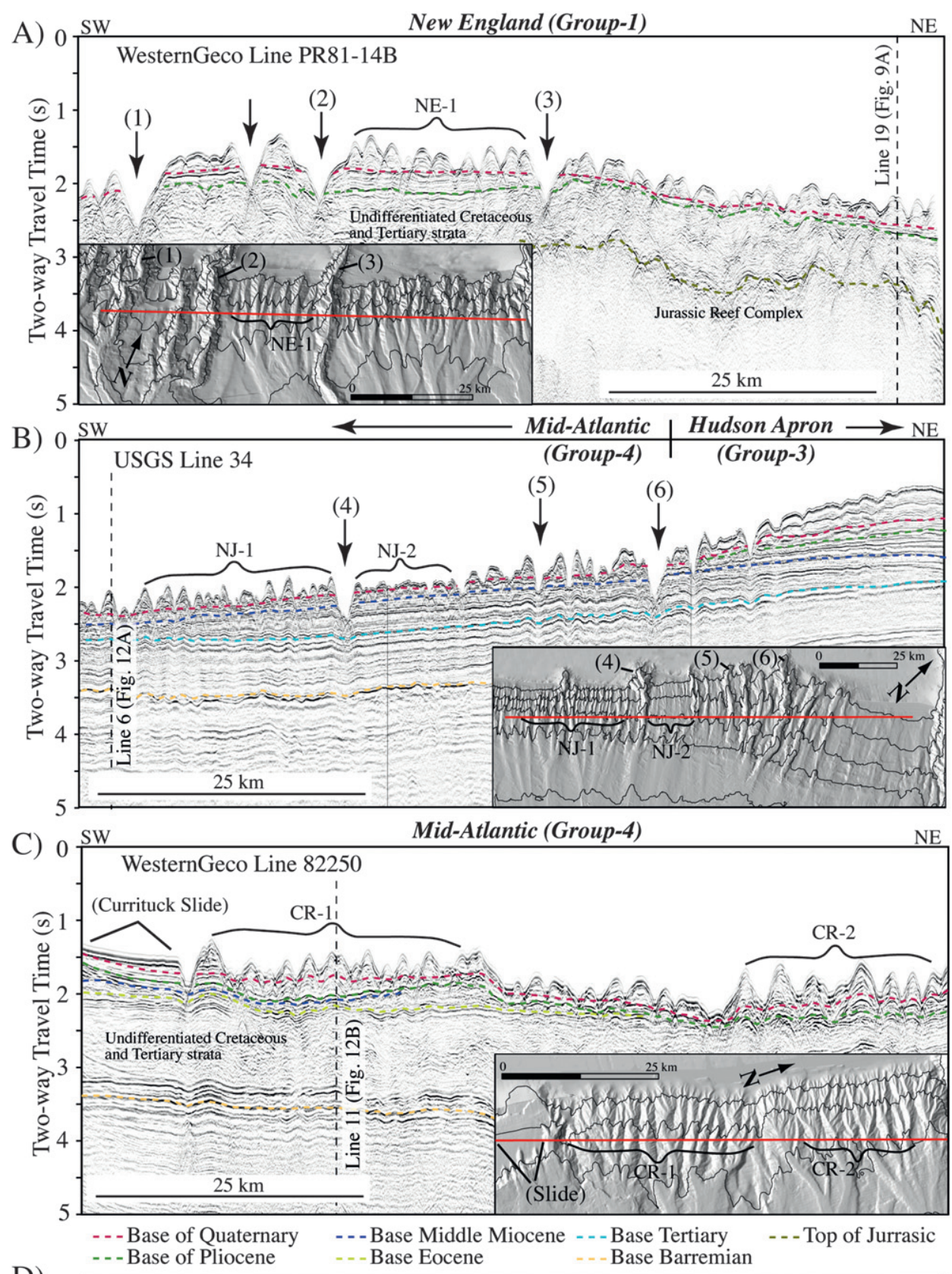

D)

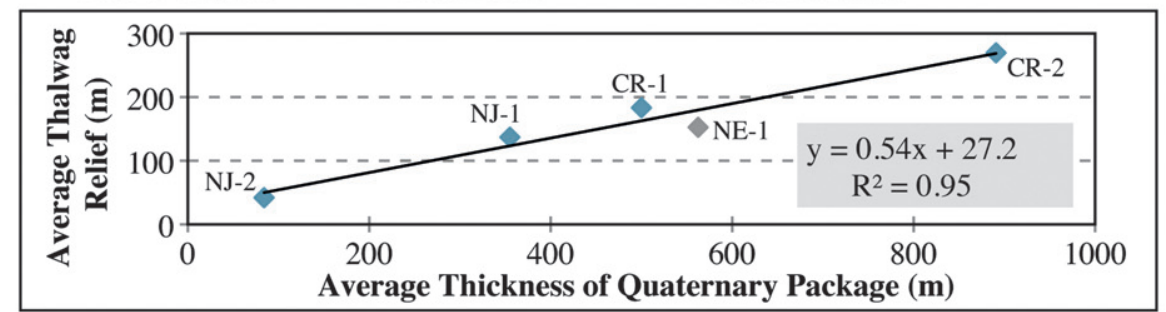

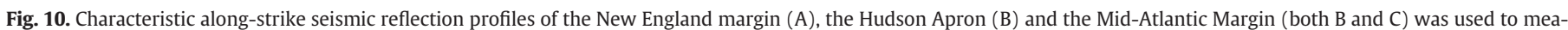

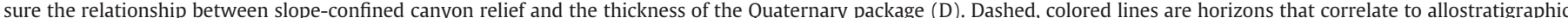

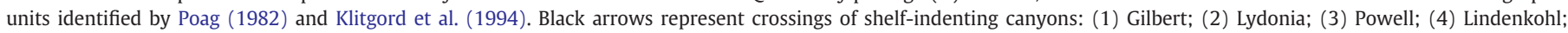

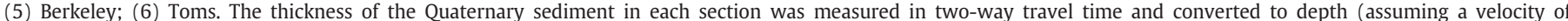

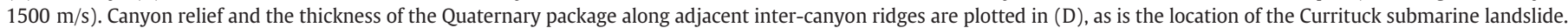

physiography appears to be the dominant factor allowing the slopes of Group-3 (i.e., the Hudson Apron) to prograde, but also the dominant factor causing widespread bypass and mass wasting along the lower and middle slope of Group-2. Sigmoidal profiles and lower canyon relief along Group 2 are largely caused by mass wasting and erosion rather than deposition. In summary, Groups 2 and 3 are 

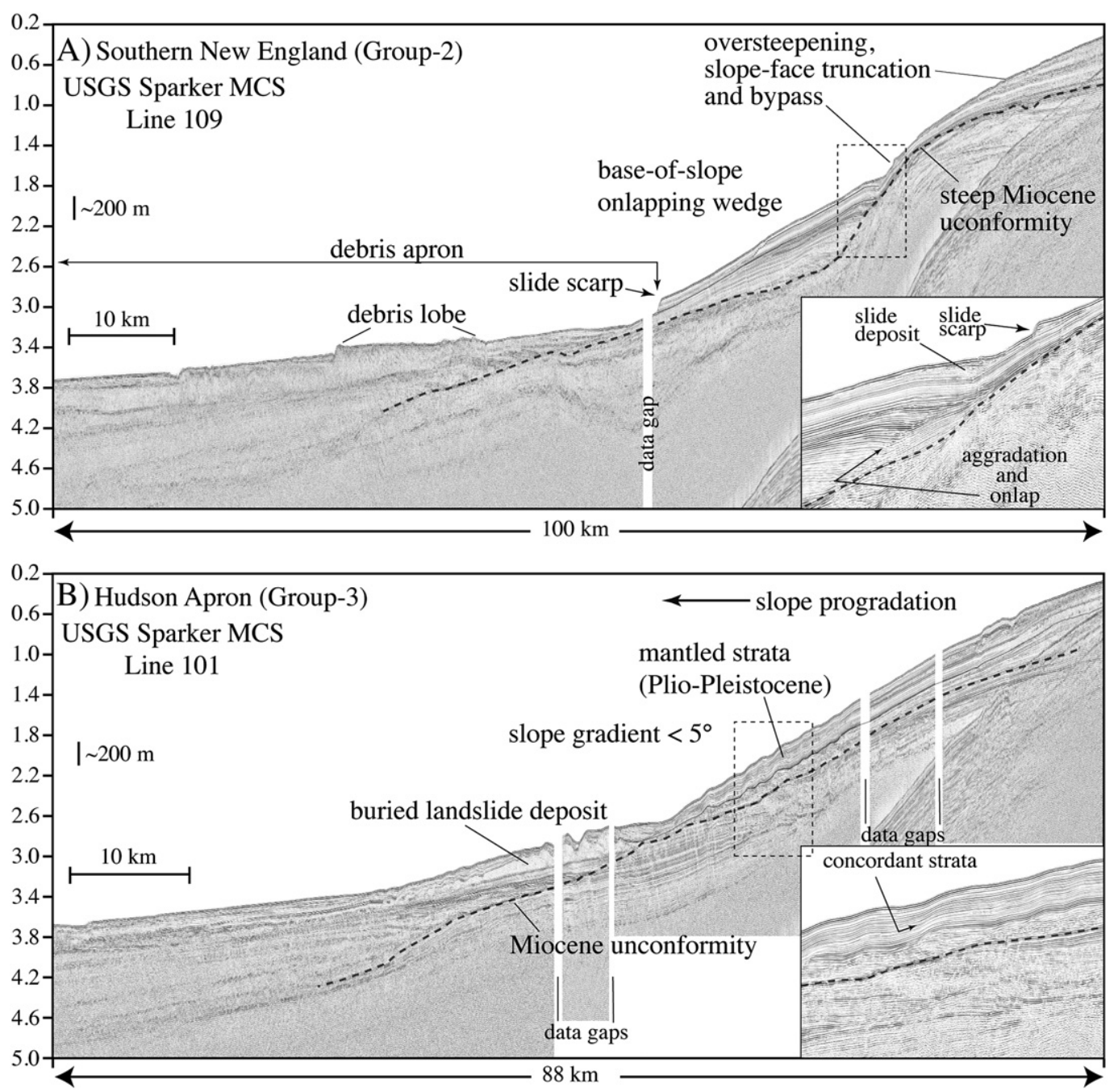

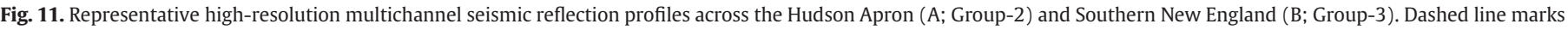

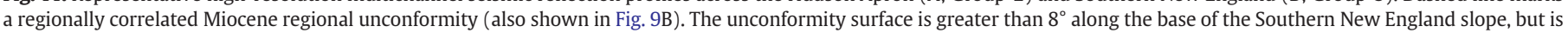

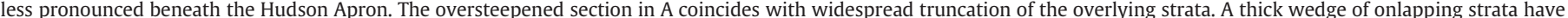

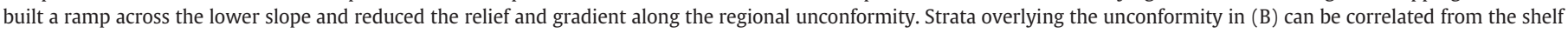
edge to the upper rise and show evidence for slope progradation.

great examples of the non-uniqueness of slope morphology and may provide excellent case studies of slope progradation as a function of pre-existing physiography.

\subsection{Mid-Atlantic (Group-4; Areas 13-17)}

The narrow $(<20 \mathrm{~km})$, concave slopes and sharp shelf-break of the Mid-Atlantic embody the oblique end-member profile (Fig. 14F). The Mesozoic reef bank is buried beneath the upper rise and has minimal influence on the present-day morphology of the continental slope (Fig. 12). Pliocene/Pleistocene sequences of fine-grained sand and silt underlie the shelf edge (Schlee et al., 1979; Poag, 1984) and truncated Middle Miocene shelf-edge delta sequences underlie the steepest section of the slope. The lower slope gradient decreases abruptly where the Middle Miocene section pinches out onto the underlying gently inclined $\left(1-2^{\circ}\right)$ Cretaceous/Tertiary ramp (Fig. 12). The change in gradient also coincides with increasing thickness of onlapping Pleistocene fan-apron deposits and increasing canyon relief between depths of 1500 and 2000 m (Figs. 12 and 13).

Pleistocene deltas prograded across the underlying late-Miocene/ Pliocene shelf-edge of the Mid-Atlantic (Fig. 12B; Poag, 1985). The angular nature of the shelf-edge suggests progradation occurred across a relatively low-energy environment and that the transition between current driven and gravity driven transport regimes was abrupt (Fig. 2A; Schlager and Adams, 2001). Assuming mass flows are sourced from the upper to middle slope, the wedge of Pleistocene shelf-edge sediment is a likely source for erosive turbidity flows that bypass the middle and lower slopes. The areas to the south of the New Jersey margin (Areas 14-17) contain thick, onlapping Pleistocene fan-apron sequences. Along canyon interfluves, these wedges have graded the transition between the lower slope and upper rise (Fig. 7). Within canyons, relief increases where the onlapping wedge is thickest, which suggests that relief of slope-sourced canyons may be a proxy for the thickness of less resistant (e.g., Quaternary) sediment accumulations. Along the New Jersey margin (Area 13) the slope-rise transition is relatively abrupt and canyon/channel relief of the lower slope/upper rise is low, possibly because less resistant Pleistocene deposits are thin or nonexistent and the uppermost rise has very low gradients. In general, slope progradation appears unlikely until the steep gradients of the upper slope are reduced, and in the case of New Jersey (Area 13), until aggradation of the uppermost rise builds a lower-gradient ramp across the lowermost slope. 

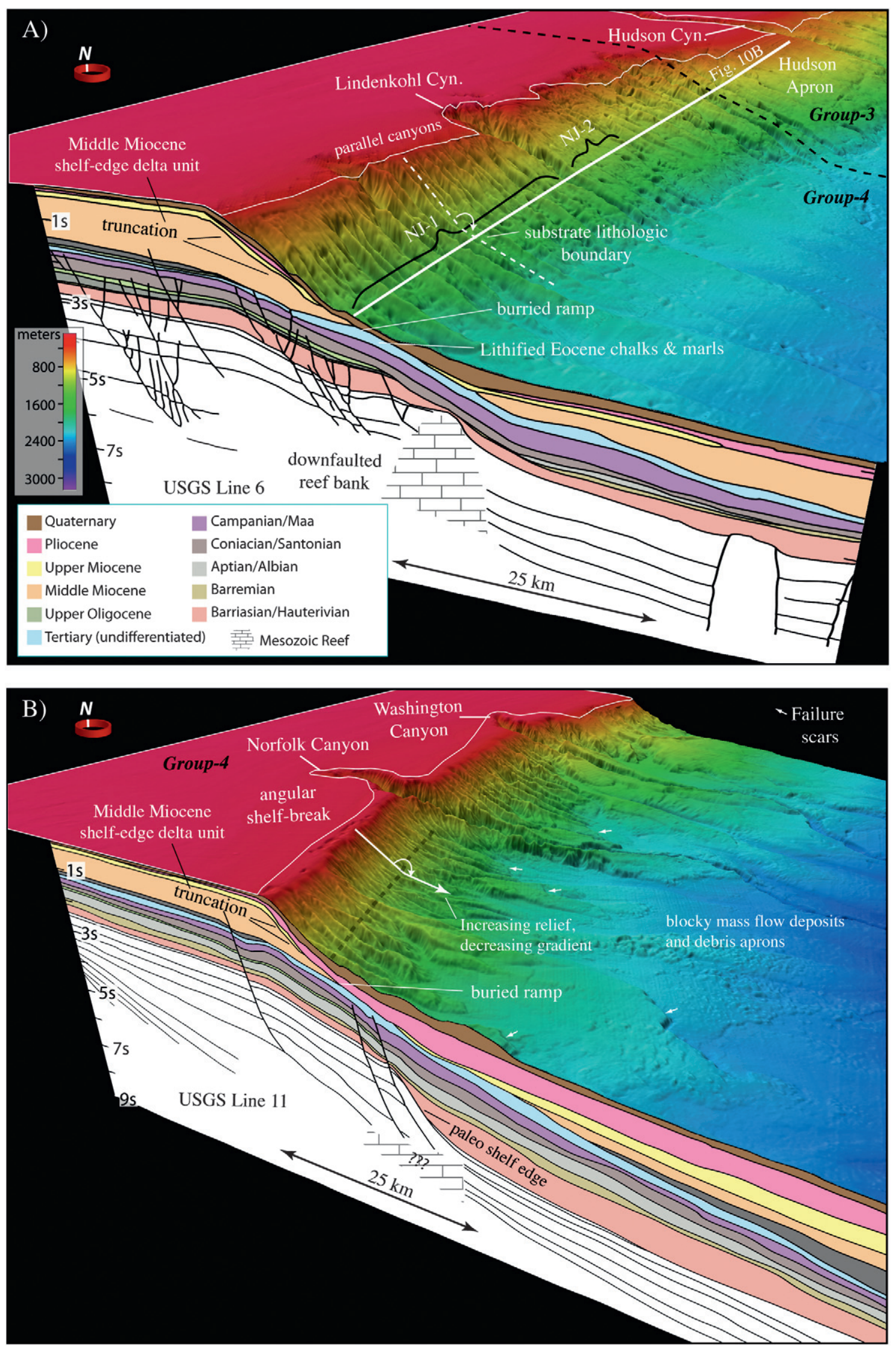

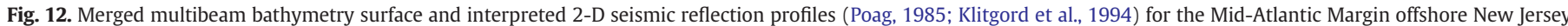

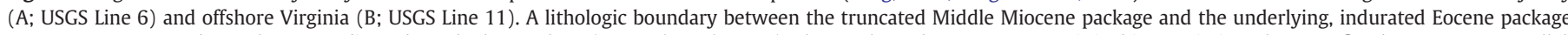

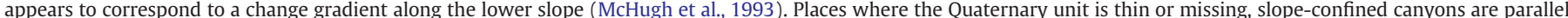

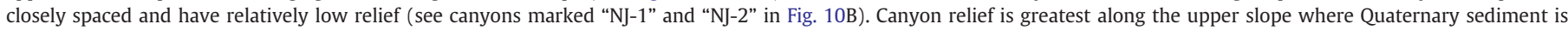
thicker. Note the increasing relief downslope in (B). 

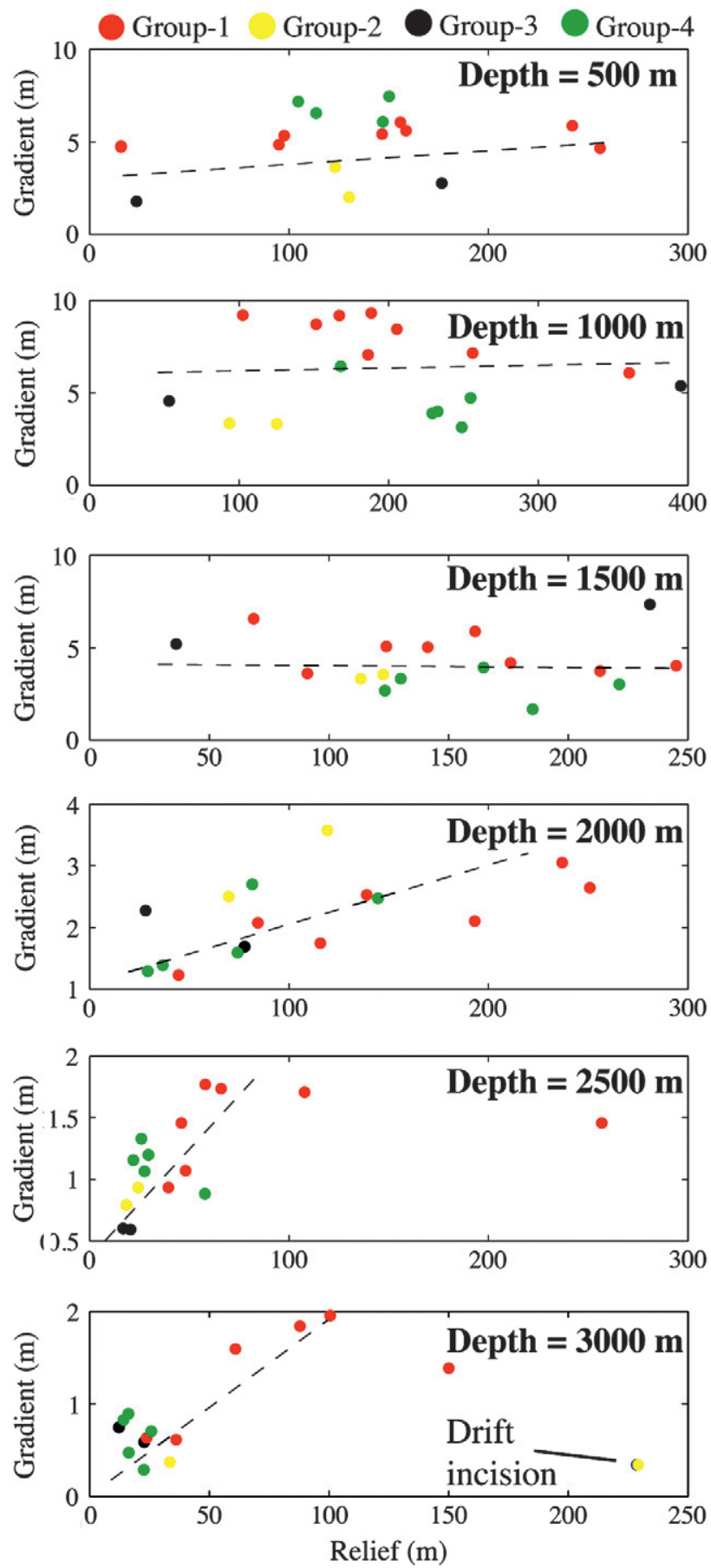

Fig. 13. Plots of average gradient versus average canyon relief along 500-m isobaths Relationship appears random from 500 to $1500 \mathrm{~m}$ depths. From 2000 to $3000 \mathrm{~m}$ depths (lower slope and upper rise) higher gradients are associated with deeper canyon incision.

\section{Conclusions}

Despite the appeal of simple, quantitative approaches to predicting the causal relationships between margin morphology and sedimentary processes, the importance of inherited physiography in slope depositional systems cannot be overlooked. Tying geomorphic classifications to particular process regimes requires a thorough examination of the underlying slope stratigraphy. By integrating rigorous morphometric analysis with geophysical constraints on substrate architecture, we conclude that morphological categorization the U.S. Atlantic margin on its own does not provide a reliable framework to predict first-order relationships between form and process. The steep Mesozoic reef bank beneath the New England margin appears to have had a profound influence on the evolution and modern-day steepness of the slope. Early Cenozoic stratigraphic packages along the upper and middle slope of Southern New England and the Hudson Apron had gentle, sigmoidal forms that are nearly maintained today. The Hudson Apron represents the only region that experienced widespread progradation during the Quaternary. Last, oblique slopes of the Middle Atlantic are largely inherited from mid-Miocene shelf-edge delta accumulation, oversteepening and subsequent erosion of the slope-face.

In each region, Quaternary sedimentary processes appear to have preserved much of the pre-Quatnerary, across-margin shape of the continental slope, but did exert heavy modification/development of submarine canyon networks, landslides and the broad-scale morphology of the continental rise. The rise was substantially altered by aggradation of thick Quaternary fan-apron and mass flow deposits because most sediment delivered to the margin bypassed the outer shelf and slope due to strong currents and steep gradients. We observe the following relationships between Quaternary sedimentary processes and margin morphology: (1) shelf-break angularity and average canyon relief along the upper slope reflect variable energy conditions along the outer shelf and upper slope; (2) pre-existing basin physiography influences spatial patterns of bypass and deposition during the Quaternary; (3) the average seafloor gradient and slope-sourced canyon relief on the lower slope and upper rise appear to be reasonable proxies for the accumulation of poorly consolidated sediment.

Supplementary data to this article can be found online at http:// dx.doi.org/10.1016/j.margeo.2012.12.008.

\section{Acknowledgments}

We would like to thank D. Twichell, W. Schwab and D. O'Grady for helpful reviews. This work was funded by the USGS Mendenhall Postdoctoral Fellowship Program and the U.S. Nuclear Regulatory Commission. Neither the U.S. Government, the Department of the Interior, nor the USGS, nor any of their employees, contractors, or subcontractors, make any warranty, express or implied, nor assume any legal liability or responsibility for the accuracy, completeness, or usefulness of any information, apparatus, product, or process disclosed, nor represent that its use would not infringe on privately owned rights. The act of distribution shall not constitute any such warranty, and no responsibility is assumed by the USGS in the use of these data or related materials. Any use of trade, product, or firm names is for descriptive purposes only and does not imply endorsement by the U.S. Government.

\section{References}

Adams, E.W., Schlager, W., 2000. Basic types of submarine slope curvature. Journal of Sedimentary Research 70, 814-828.

Amante, C., Eakins, B.W., 2009. ETOPO1 1 arc-minute global relief model: procedures, data sources and analysis. NOAA Technical Memorandum NESDIS NGDC-24.

Austin, J.A., Uchupi, E., Shaughnessy, D., Ballard, R.D., 1980. Geology of New England passive margin. American Association of Petroleum Geologists Bulletin 64, 501-526.

Booth, J.S., O'Leary, D.W., Popenoe, P., Danforth, W.W., 1993. U.S. Atlantic Continental Slope Landslides: Their Distribution, General Attributes, and Implications.

Cacchione, D.A., Pratson, L.F., Ogston, A.S., 2002. The shaping of continental slopes by internal tides. Science 296, 724-727.

Chaytor, J.D., ten Brink, U.S., Solow, A.R., Andrews, B.D., 2009. Size distribution of submarine landslides along the US Atlantic margin. Marine Geology 264, 16-27.

Chaytor, J.D., Twichell, D., ten Brink, U.S., 2012. Reevaluation of the Munson-NygrenRetriever Submarine Landslide Complex. Georges Bank Lower Slope, Western North Atlantic.

Dillon, W.P., Popenoe, P., 1988. The Blake Plateau Basin and Carolina Trough. Geological Society of America, Boulder.

Emery, K.O., Uchupi, E., 1965. Structure of Georges Bank. Marine Geology 3, 349-358.

Flores, C.H., Brothers, D.S., ten Brink, U.S., Chaytor, J.D., 2011. New Geophysical Constraints on the Stratigraphy and Structure of the Southern New England Continental Margin, Fall Meeting Suppl. Abstract. American Geophysical Union. 

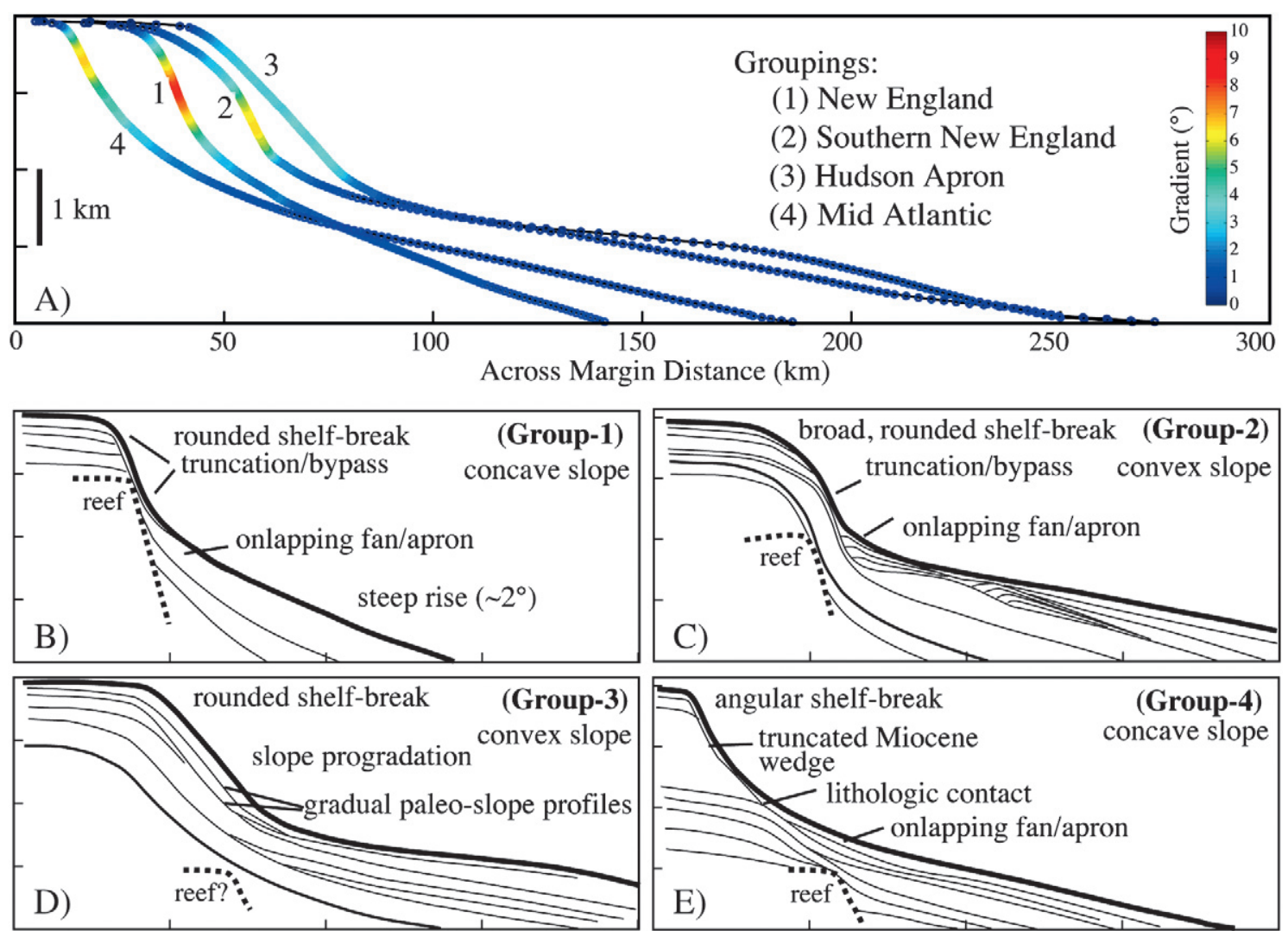

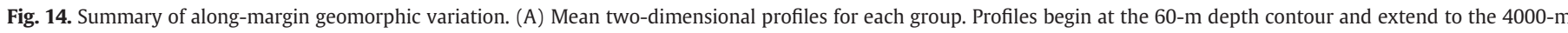

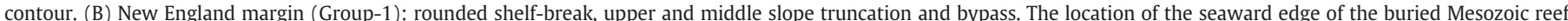

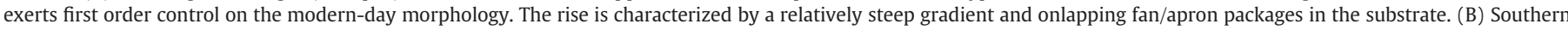

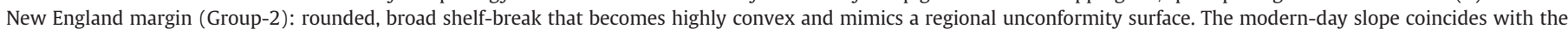

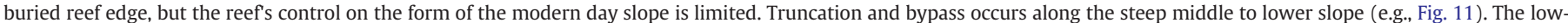

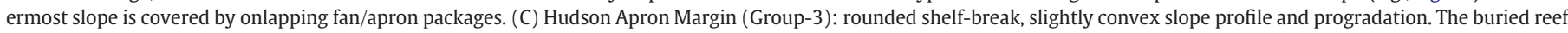

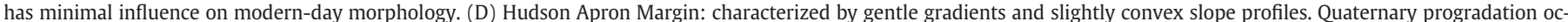

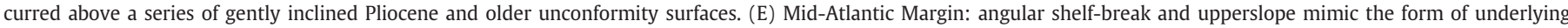

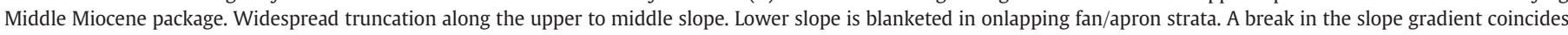
with the lithologic contact between the Miocene wedge and a buried Cretaceous ramp that prograded over the Mesozoic reef bank.

Galloway, W.E., 1998. Siliciclastic slope and base-of-slope depositional systems: component facies, stratigraphic architecture, and classification. AAPG Bulletin 82, 569-595.

Gerber, T.P., Amblas, D., Wolinsky, M.A., Pratson, L.F., Canals, M., 2009. A model for the long-profile shape of submarine canyons. Journal of Geophysical Research - Earth Surface 114.

Goff, J.A., 2001. Quantitative classification of canyon systems on continental slopes and a possible relationship to slope curvature. Geophysical Research Letters 28 4359-4362.

Greenlee, S.M., Devlin, W.J., Miller, K.G., Mountain, G.S., Flemings, P.B., 1992. Integrated sequence stratigraphy of Neogene deposits, New-Jersey continental-shelf and slope - comparison with the Exxon model. Geological Society of America Bulletin 104, 1403.

Grow, J.A., Klitgord, K.D., Schlee, J., Dillon, W.P., 1988. Representative seismic profiles of U.S. Atlantic continental margin. In: Sheridan, R.E., Grow, J.A. (Eds.), The Geology of North America. The Atlantic Continental Margin, vol. I-2. U.S. Geological Society of America, Boulder.

Harman, H.H., 1976. Modern Factor Analysis, 3 ed. University of Chicago Press, Chicago.

Holbrook, W.S., Purdy, G.M., Collins, J.A., Sheridan, R.E., Musser, D.L., Glover, L., Talwani, M., Ewing, J.I., Hawman, R., Smithson, S.B., 1992. Deep velocity structure of rifted continental-crust, United-States Mid-Atlantic margin, from wide-angle reflection refraction data. Geophysical Research Letters 19, 1699-1702.

Hutchinson, D.R., Klitgord, K.D., Detrick, R.S., 1986. Rift basins of the long-island platform. Geological Society of America Bulletin 97, 688-702.

Hutchinson, D.R., Poag, C.W., Popenoe, P., 1996. Geophysical Database of the East Coast, of the United States: Southern Atlantic Margin-Stratigraphy and Velocity from Multichannel Seismic Profiles. US Geol. Survey Open File Report 95-27.

Kenter, J.A.M., 1990. Carbonate platform flanks - slope angle and sediment fabric. Sedimentology 37, 777-794.

Kenyon, P.M., Turcotte, D.L., 1985. Morphology of a delta prograding by bulk sediment transport. Geological Society of America Bulletin 96, 1457-1465.
Klitgord, K.D., Hutchinson, D.R., Schouten, H., 1988. Atlantic Continental Margin: Structural and Tectonic Framework. Geological Society of America, Boulder.

Klitgord, K.D., Poag, C.W., Schneider, C.M., North, L., 1994. Geophysical Database of the East Coast of the United States Northern Atlantic Continental Margin: Cross Sections and Gridded Database (Georges Bank Basin, Long Island Platform, and Baltimore Canyon Trough). US Geol. Survey Open-File Report 94-637.

Lizarralde, D., Holbrook, W.S., 1997. US mid-Atlantic margin structure and early thermal evolution. Journal of Geophysical Research - Solid Earth 102, 22855-22875.

Manspeizer, W., 1985. Early Mesozoic History of the Atlantic Passive Margin. Van Nostrand Reinhold Company, New York.

McAdoo, B.G., Pratson, L.F., Orange, D.L., 2000. Submarine landslide geomorphology, US continental slope. Marine Geology 169, 103-136.

McHugh, C.M.G., Olson, H.C., 2002. Pleistocene chronology of continental margin sedimentation: new insights into traditional models, New Jersey. Marine Geology 186, 389-411.

McHugh, C.M., Ryan, W.B.F., Schreiber, B.C., 1993. The role of diagenesis in exfoliation of submarine canyons. American Association of Petroleum Geologists Bulletin 77, 145-172.

McHugh, C.M.G., Damuth, J.E., Mountain, G.S., 2002. Cenozoic mass-transport facies and their correlation with relative sea-level change, New Jersey continental margin. Marine Geology 184, 295-334.

Miller, K.G., Mountain, G.S., Tucholke, B.E., 1985. Oligocene glacio-eustasy and erosion on the margins of the North-Atlantic. Geology 13, 10-13.

Mitchell, N.C., 2004. Form of submarine erosion from confluences in Atlantic USA continental slope canyons. American Journal of Science 304, 590-611.

Mitchell, N.C., 2005. Interpreting long-profiles of canyons in the USA Atlantic continental slope. Marine Geology 214, 75-99.

Mitchell, N.C., 2006. Morphologies of knickpoints in submarine canyons. Geological Society of America Bulletin 118, 589-605.

Mitchum, R.M., Vail, P., Thompson, S., 1977. Seismic stratigraphy and global changes of sea level; part 2. The depositional sequence as a basic unit for stratigraphic analysis. In: Payton, C.E. (Ed.), Seismic Stratigraphy; Applications to Hydrocarbon Exploration. American Association of Petroleum Geologists, Tulsa, OK, pp. 53-62. 
Monteverde, D.H., Mountain, G.S., Miller, K.G., 2008. Early Miocene sequence development across the New Jersey margin. Basin Research 20, 249-267.

Mountain, G., Tucholke, B.E., 1985. Mesozoic and Cenozoic Geology of the U.S. Atlantic Continental Slope and Rise. Van Nostrand Reinhold Company, New York.

NOAA, 2010. National Geophysical Data Center, U.S. Coastal Relief Model.

O'Grady, D.B., Syvitski, J.P.M., Pratson, L.F., Sarg, J.F., 2000. Categorizing the morphologic variability of siliciclastic passive continental margins. Geology 28, 207-210.

Oldale, R.N., 1992. Cape Cod and the Islands: the Geologic Story. Parnassus Imprints, East Orleans, MA

O'Leary, D.W., 1986. Seismic Structure and Stratigraphy of the New England Continental Slope and Evidence for Slope Instability. US Geol. Survey Open File Report 86-118, 182.

O'Leary, D.W., Dobson, M.R., 1992. Southeastern New England Continental Rise: Origin and History of Slide Complexes. Van Nostrand Reinhold, New York.

Olsen, P.E., 1997. Stratigraphic record of the early Mesozoic breakup of Pangea in the Laurasia-Gondwana rift system. Annual Review of Earth and Planetary Sciences 25, 337-401.

Orton, G.J., Reading, H.G., 1993. Variability of deltaic processes in terms of sediment supply, with particular emphasis on grain-size. Sedimentology 40, 475-512.

Peltier, W.R., 1996. Global sea level rise and glacial isostatic adjustment: an analysis of data from the East Coast of North America. Geophysical Research Letters 23, 717-720.

Pirmez, C., Pratson, L.F., Steckler, M.S., 1998. Clinoform development by advection-diffusion of suspended sediment: modeling and comparison to natural systems. Journal of Geophysical Research - Solid Earth 103, 24141-24157.

Poag, C.W., 1978. Stratigraphy of Atlantic continental-shelf and slope of United-States. Annual Review of Earth and Planetary Sciences 6, 251-280.

Poag, C.W., 1982. Stratigraphic reference section for Georges Bank Basin-depositiona model for New England passive margin. American Association of Petroleum Geologists Bulletin 66, 1021-1041.

Poag, C.W., 1984. Neogene stratigraphy of the submerged United-States Atlantic margin. Palaeogeography, Palaeoclimatology, Palaeoecology 47, 103-127.

Poag, W., 1985. Geologic Evolution of the United States Atlantic Margin. Van Nostrand Reinhold, New York, NY.

Poag, C.W., 1992. U.S. Middle Atlantic Continental Rise: Provenance, Dispersal, and Deposition of Jurassic to Quaternary Sediments. Van Nostrand Reinhold, New York.

Poag, C.W., Sevon, W.D., 1989. A record of Appalachian denudation in postrift Mesozoic and Cenozoic sedimentary deposits of the US middle Atlantic continental margin. Geomorphology 2, 119-157.

Poulsen, C.J., Flemings, P.B., Robinson, R.A.J., Metzger, J.N., 1998. Three-dimensional stratigraphic evolution of the Miocene Baltimore Canyon region: implications for eustatic interpretations and the systems tract model. Geological Society of America Bulletin 110, 1105-1122.

Pratson, L.F., Coakley, B.J., 1996. A model for the headward erosion of submarine canyons induced by downslope-eroding sediment flows. Geological Society of America Bulletin 108, 225-234.

Pratson, L.F., Haxby, W.F., 1996. What is the slope of the US continental slope? Geology 24, 3-6.

Pratson, L.F., Ryan, W.B.F., Mountain, G.S., Twichell, D.C., 1994. Submarine-canyon initiation by downslope-eroding sediment flows - evidence in Late Cenozoic strata on the New-Jersey continental-slope. Geological Society of America Bulletin 106, 395-412.
Pratt, R.M., Schlee, J., 1969. Glaciation on continental margin off New England. Geological Society of America Bulletin 80, 2335

Reyment, R.A., Joreskog, K.G., 1993. Applied Factor Analysis in the Natural Sciences. Cambridge University Press, New York.

Robb, J.M., Kirby, J.R., Hampson, J.C., Gibson, P.R., Hecker, B., 1983. Furrowed outcrops of Eocene chalk on the lower continental-slope offshore New-Jersey. Geology 11, $182-186$.

Ross, W.C., Halliwell, B.A May, J.A, Watts, D.E., Syvitski, J.P.M., 1994. Slope readjustment - a new model for the development of submarine fans and aprons. Geology 22, 511-514

Schlager, W., Adams, E.W., 2001. Model for the sigmoidal curvature of submarine slopes. Geology 29, 883-886.

Schlager, W., Camber, O., 1986. Submarine slope angles, drowning unconformities, and self-erosion of limestone escarpments. Geology 14, 762-765.

Schlee, J.S., Poag, C.W., 1980. Seismic stratigraphy of Atlantic margin in vicinity of Chevron Cost B-3 well. American Association of Petroleum Geologists Bulletin 64, 781

Schlee, J.S., Berhendt, J.C., Grow, J.A., Robb, J.M., Mattick, R.E., Taylor, P.T., Lawson, B.J., 1976. Regional geologic framework off northeastern United States. American Association of Petroleum Geologists Bulletin 60, 926-951.

Schlee, J., Dillon, W.P., Grow, J.A., 1979. Structure of the continental slope off eastern United States. In: Doyle, L.J., Piley, O.H. (Eds.), Geology of Continental Slopes. Society of Economic Paleontologists and Mineralogists, Tulsa, OK

Schlee, J., Poag, C.W., Hinz, K., 1985. Seismic Stratigraphy of the Continental Slope and Rise Seaward of Georges Bank. Van Nostrand Reinhold Company, New York.

Steckler, M.S., Watts, A.B., Thorne, J.A., 1988. Subsidence and Basin Modeling at the U.S. Atlantic Passive Margin. Geological Society of America, Boulder, CO.

Twichell, D.C., Roberts, D.G., 1982. Morphology, distribution, and development of submarine canyons on the United-States Atlantic continental-slope between Hudson and Baltimore canyons. Geology 10, 408-412.

Twichell, D.C., Chaytor, J.D., ten Brink, U.S., Buczkowski, B., 2009. Morphology of late Quaternary submarine landslides along the US Atlantic continental margin. Marine Geology 264, 4-15.

Uchupi, E., Oldale, R.N., 1994. Spring sapping origin of the enigmatic relict valleys of Cape-Cod and Marthas-Vineyard and Nantucket Islands, Massachusetts. Geomorphology 9, 83-95.

Valentine, P.C., Uzmann, J.R., Cooper, R.A., 1980. Geology and biology of oceanographer submarine-canyon. Marine Geology 38, 283-312.

Van Wagoner, J.C., Posamentier, H.W., Mitchum, R.M., Vail, P.R., Sarg, J.F., Loutit, T.S. Hardenbol, J., 1988. An Overview of the Fundamentals of Sequence Stratigraphy and Key Definitions. SEPM, Tulsa.

Williams, H., Hatcher, R.D., 1982. Suspect terranes and accretionary history of the Appalachian orogen. Geology 10, 530-536.

Withjack, M.O., Schlische, R.W., 2005. A review of tectonic events on the passive margin of eastern North America. In: Post, P. (Ed.), Petroleum Systems of Divergent Continental Margin Basins: 25th Bob S. Perkins Research Conference, Gulf Coast Section of SEPM. SEPM, pp. 203-235.

Wyer, P., Watts, A.B., 2006. Gravity anomalies and segmentation at the East Coast, USA continental margin. Geophysical Journal International 166, 1015-1038. 